\title{
Impacts of exotic mangrove forests and mangrove deforestation on carbon remineralization and ecosystem functioning in marine sediments
}

\author{
A. K. Sweetman ${ }^{1, *}$, J. J. Middelburg ${ }^{2,3}$, A. M. Berle ${ }^{4}$, A. F. Bernardino ${ }^{5}$, C. Schander $^{4}$, A. W. J. Demopoulos ${ }^{6}$, and \\ C. R. Smith ${ }^{7}$ \\ ${ }^{1}$ Norwegian Institute for Water Research (NIVA), Thormøhlensgate 53D, 5006 Bergen, Norway \\ ${ }^{2}$ Centre for Estuarine and Marine Ecology, Netherlands Institute of Ecology, P.O. Box 140, 4400 AC Yerseke, \\ The Netherlands \\ ${ }^{3}$ Faculty of Geosciences, Utrecht University, P.O. Box 80021, 3508 TA Utrecht, The Netherlands \\ ${ }^{4}$ Department of Biology, University of Bergen, P.O. Box 7800, 5020 Bergen, Norway \\ ${ }^{5}$ Departamento de Oceanografia e Ecologia, Universidade Federal do Espirito Santo (UFES), Vitória, ES, Brazil \\ ${ }^{6}$ US Geological Survey, Florida Integrated Science Center, FISC-Gainesville, 7920 NW 71st Street, Gainesville, \\ Florida, 32653, USA \\ ${ }^{7}$ Department of Oceanography, University of Hawaii at Manoa, 1000 Pope Road, Honolulu, Hawaii, 96822, USA \\ * formerly at: Department of Oceanography, University of Hawaii at Manoa, 1000 Pope Road, Honolulu, HI 96822, USA
}

Received: 28 March 2010 - Published in Biogeosciences Discuss.: 9 April 2010

Revised: 19 June 2010 - Accepted: 23 June 2010 - Published: 8 July 2010

\begin{abstract}
To evaluate how mangrove invasion and removal can modify short-term benthic carbon cycling and ecosystem functioning, we used stable-isotopically labeled algae as a deliberate tracer to quantify benthic respiration and $\mathrm{C}$-flow over $48 \mathrm{~h}$ through macrofauna and bacteria in sediments collected from (1) an invasive mangrove forest, (2) deforested mangrove sites 2 and 6 years after removal of above-sediment mangrove biomass, and (3) two mangrove-free control sites in the Hawaiian coastal zone. Sediment oxygen consumption (SOC) rates averaged over each $48 \mathrm{~h}$ investigation were significantly greater in the mangrove and mangrove removal site experiments than in controls and were significantly correlated with total benthic (macrofauna and bacteria) biomass and sedimentary mangrove biomass (SMB). Bacteria dominated short-term Cprocessing of added microalgal-C and benthic biomass in sediments from the invasive mangrove forest habitat and in the 6-yr removal site. In contrast, macrofauna were the most important agents in the short-term processing of microalgal$\mathrm{C}$ in sediments from the 2-yr mangrove removal site and control sites. However, mean faunal abundance and C-uptake rates in sediments from both removal sites were significantly
\end{abstract}

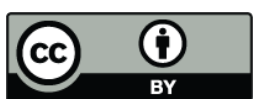

Correspondence to: A. K. Sweetman (asw@niva.no) higher than in control cores, which collectively suggest that community structure and short-term C-cycling dynamics of sediments in habitats where mangroves have been cleared can remain fundamentally different from un-invaded mudflat sediments for at least 6-yrs following above-sediment mangrove removal. In summary, invasion by mangroves can lead to dramatic shifts in benthic ecosystem function, with sediment metabolism, benthic community structure and shortterm C-remineralization dynamics being affected for years following invader removal.

\section{Introduction}

Marine vascular plants can influence a variety of aboveand below-sediment physical and chemical characteristics, and consequently can alter the species composition and trophic structure of benthic communities (Talley and Levin, 1999; Levin et al., 2006; Alongi, 2009). Thus, vascular plants can play a large role in structuring the flow of organic material and energy in coastal habitats (Wardle et al., 2004). Mangroves are among the most widespread marine vascular plants, occupying $\sim 1.6 \times 10^{5} \mathrm{~km}^{2}$ along subtropical and tropical coastlines (Alongi, 2002, 2008), where they play important ecosystem roles, serving as nursery grounds for commercially important fishes and invertebrates

Published by Copernicus Publications on behalf of the European Geosciences Union. 
(Manson et al., 2005), and as nesting habitats for a variety of birds (Nagelkerken et al., 2008). Mangroves also act as major ecosystem engineers by reducing water flow and trapping sediments, which can lead to enhanced densities of deposit feeding fauna (Demopoulos, 2004; Demopoulos and Smith, 2010), as well as limiting coastal erosion, and providing a buffer to tropical storms and tsunamis (Environmental Justice Foundation report 2006). They also effectively sequester nutrients (Middelburg et al., 1996; Bouillon et al., 2008), and may enhance water quality in surrounding habitats by reducing eutrophication and turbidity (Valiela and Cole, 2002; Victor et al., 2004).

Despite suitable seawater temperatures $\left(>20^{\circ} \mathrm{C}\right)$, the geographic isolation of the Hawaiian Archipelago excluded mangroves from the Hawaiian Islands until 1902, when the red mangrove, Rhizophora mangle, was introduced from Florida to Moloka'i to stabilize coastal erosion from pastures and sugarcane fields (Chimner et al., 2006). Mangroves have now invaded large portions of the intertidal and high subtidal zone along the island of O'ahu, and in 2001, the total area of mangroves on O'ahu was $1500 \mathrm{~km}^{2}$ (Chimner et al., 2006).

Recent studies have examined the effects of marine vascular plant invasions on coastal habitats, in particular in saltmarshes (Talley and Levin 1999, Levin et al., 2006). It is now known that invasive marine vascular plants can cause local species extinctions (Grosholz, 2002) and habitat modification (Bromberg-Gedan et al., 2009). In Hawaii, the establishment of $R$. mangle has dramatically altered macrofaunal species and food-web structure, facilitating greater dominance by sub-surface deposit feeders, and creating new niches for other exotic species in mangrove sediments (Demopoulos, 2004; Demopoulos et al., 2007; Demopoulos and Smith, 2010). However, the impacts of $R$. mangle invasion on benthic ecosystem functioning, in particular, how mangroves modify sediment metabolism and C-remineralization processes in the Hawaiian coastal zone, remain essentially unexplored. Rhizophora mangle detritus is rich in tannins, which can be toxic to benthic detritivores, interfering with digestive enzymes (Mahadevan and Muthukumar, 1980; Neilson et al., 1986; Alongi, 1987; Sessegolo and Lana, 1991). Therefore, we postulate that mangrove invasion will favor microbial C-remineralization processes by limiting macrofaunal consumption and assimilation of detrital carbon (Alongi, 1987; Boto et al., 1989; Tietjen and Alongi, 1990; Robertson et al., 1992).

Because invasive species can considerably damage natural and managed ecosystems, strategies have been developed to control, contain and/or eradicate invasive species. However, eradication or removal of invasive species alone may not allow ecosystems to rapidly or even completely recover original ecosystem function because invaders can substantially alter physical, chemical and biological conditions (Zavaleta et al., 2001). In Hawaii, the success of $R$. mangle has created a suite of environmental problems (e.g. clogging of streams and fish ponds, invasion of bird sanctuaries), leading to nu- merous removal projects in the coastal zone. Typical mangrove clearing practices in Hawaii include the removal of the above-sediment mangrove biomass, but leaving intact the prop roots and the root-fiber mat within the sediment (Sweetman personal observations). Mangrove roots and fiber-mats are also rich in tannins and bind sediments, which may hamper faunal movement and impede bioturbation. Few data are available concerning benthic ecosystem functioning in deforested, native mangrove forests worldwide (Sjöling et al., 2005), and we know of no data on the effects of the removal strategy employed in Hawaii on benthic ecosystem functioning and recovery. However, we postulate that benthic Ccycling processes may be dominated by microbes, and that sediment ecosystem function will be altered, long after mangrove removal if the toxic, nutrient trapping, root-fiber mat is not removed along with the emergent mangrove structures.

In recent years, tracer experiments with stable isotopes have proved extremely powerful in quantifying benthic ecosystem functioning in a variety of marine environments (Middelburg et al., 2000; Moodley et al., 2000; Evrard et al., 2005; van Oevelen et al., 2006). In short, an isotopically labeled substrate (e.g. ${ }^{13} \mathrm{C}$-labeled algae) is deposited over an enclosed area of seafloor and the uptake of labeled elements tracked into sediment-dwelling organisms and abiotic components (e.g. dissolved inorganic carbon), making it possible to quantify the uptake of specific elements into specific organisms and thus, identify the pathways through which certain elements cycle. In this case-study, we used stable-isotopically labeled algae as a deliberate tracer as one means to explore benthic ecosystem functioning in sediments from (1) an invasive mangrove forest, (2) mangrove removal sites 2- and 6-yrs after removal of above-sediment mangrove biomass, and (3) two mangrove-free control sites. We evaluated the effects of intact mangroves, as well as sediment root-fiber complexes remaining after mangrove removal, on respiration and C-flow though the sediment-dwelling macrofauna and bacteria. Because of the relatively short duration of each experiment ( $48 \mathrm{~h}$ ) and the addition of algal-C to the sediment surface, our experiments primarily addressed nearsurface processes, and tested the following hypotheses: (1) Biogeochemical cycling in mangrove sediments favors bacterial pathways, yielding lower macrofaunal uptake of labile organic matter than in adjacent mudflats. (2) Due to the persistence of a dense root-fiber mat, bacterial metabolism is enhanced, and macrofaunal uptake of newly added labile organic matter reduced, in sediments for years following above-sediment mangrove removal.

\section{Methods}

\subsection{Study sites}

Ex-situ experiments were carried out on sediment cores collected from 5 sites on the island of O'ahu, Hawaii (Fig. 1) 
between January and May of 2008. Three sites were located in the high subtidal zone of Pearl Harbor $(\mathrm{PH})$ and were all sampled in January 2008 (water temperature: $\sim 23-$ $27^{\circ} \mathrm{C}$ ). The mangrove site (PHM) was located $8 \mathrm{~m}$ inside a healthy $R$. mangle mangrove forest in Pouhala Marsh, Pearl Harbor. The 2-yr post-removal site (PHR) was located at the fringe of a former mangrove forest in the Pearl Harbor National Wildlife Refuge. Most living above-sediment mangrove biomass was removed from the PHR site in 2006. The third Pearl Harbor site was a mangrove-free control site (PHC) located on a mudflat at the southern end of Neal S. Blaisdell Park, approximately $60 \mathrm{~m}$ away from the nearest mangrove stand. The remaining two sites were located in the Kaneohe Bay (KB) low intertidal zone and were sampled at the beginning of May 2008 (Water temperature: 27-28 ${ }^{\circ} \mathrm{C}$ ), with the fourth site located several meters into a former $R$. mangle stand (live above sediment mangrove biomass removed in 2002) in Kahaluu, Kaneohe Bay (KBR). The fifth site was a mangrove-free, mudflat control site (KBC) located approximately $60 \mathrm{~m}$ away from the nearest mangrove stand (Fig. 1). Despite being suitable habitats for mangrove colonization, both control sites remained free of mangroves because of active seedling removal programs in the State of Hawaii. Tidal range at all sites was approximately $0.4 \mathrm{~m}$. Because of logistical constraints imposed by the Pearl Harbor naval base and the labor-intensive nature of these experiments, we were forced to study a single mangrove site in Pearl Harbor. Only single 2-yr and 6-yr removal sites were available on O'ahu, so this investigation constitutes a case study of the various habitat types.

\subsection{Experimental design}

At each sampling site, four replicate, $15 \mathrm{~cm}$ deep sediment cores were collected in $19 \mathrm{~cm}$ (i.d.) clear, acrylic benthic chambers at random locations along a $15 \mathrm{~m}$ long transect running parallel to the water's edge, so that substantial habitat heterogeneity along the shoreline was incorporated into the design. Mangrove leaf litter was only found on top of sediments from the PHM site and was not removed from sediment cores. Subtidal sediments from all Pearl Harbor sites were collected from approximately $15 \mathrm{~cm}$ water depth at low tide, and those collected at the PHM site were sampled between prop roots at a distance of approximately $0.5 \mathrm{~m}$ from individual emergent roots. Intertidal sediment cores from both Kaneohe Bay sites were collected along a $15 \mathrm{~m}$ long transect line at an identical tidal elevation above the low tide mark at low tide. Immediately after collection, all cored sediments were covered with $25 \mathrm{~cm}$ of top water and transported to Waikiki Aquarium where they were placed in a temperature controlled water bath $\left(24^{\circ} \mathrm{C}\right)$. Sediments were allowed to settle, and conditions in each chamber allowed to equilibrate for $24 \mathrm{~h}$ prior to the start of the experiments. Pilot studies revealed that $24 \mathrm{~h}$ was sufficient time to allow settlement of sediments re-suspended during chamber transport.

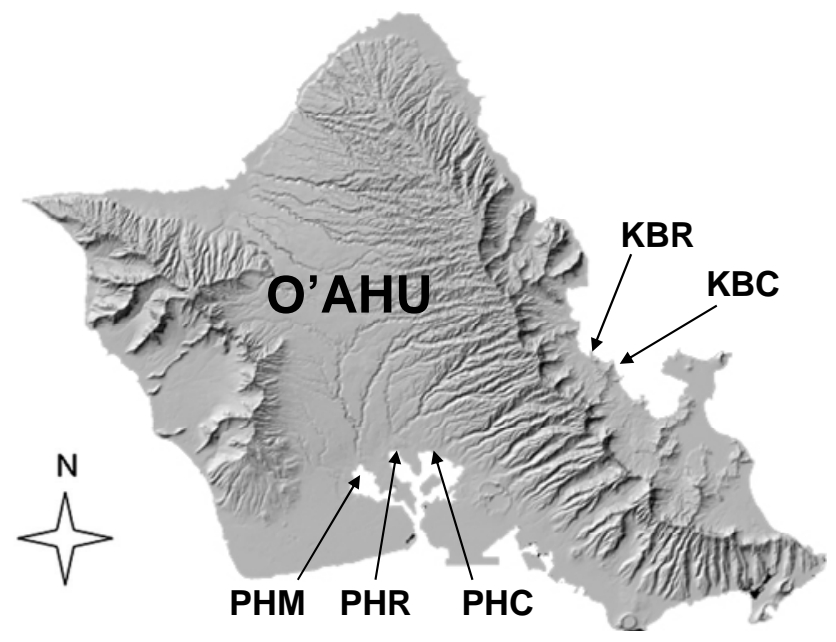

Fig. 1. Location of the 5 sampling sites on the island of O'ahu, Hawaii.

A non-axenic clone of the green alga Chlorella spp. (Chlorophyta), initially sampled off the coast of Hawaii, was used as a food source in our experiments. Whilst this labile $\mathrm{C}$-source is physically and biochemically distinct from relatively refractory mangrove material, labile algal-C is known to continuously enter and support mangrove ecosystems through natural processes including phytodetritus deposition and benthic microalgal production (Bouillon et al., 2008; Oakes et al., 2010). This type of addition is therefore not entirely artificial and allowed us to realistically trace the fate of labile algal-C in mangrove type environments and therefore, quantify various aspects of ecosystem functioning in the sites studied. Phytoplankton was cultured for 3 weeks at $24^{\circ} \mathrm{C}$ under a 16: $8 \mathrm{~h}$ light: dark cycle in artificial seawater modified with $\mathrm{F} / 2$ algal culture medium (Grasshoff et al., 1999), and labeled by replacing $25 \%$ of ${ }^{12} \mathrm{C}$ bicarbonate in the culture medium with $\mathrm{NaH}^{13} \mathrm{CO}_{3}$. For harvest, inocula were concentrated by centrifugation $(404 \times \mathrm{g}, 5 \mathrm{~min})$, washed 5 times in a isotonic solution to remove excess labeled bicarbonate, and freeze dried. Algae samples possessed a ${ }^{13} \mathrm{C}$-content, $\delta^{13} \mathrm{C}$-signature, and molar $\mathrm{C}: \mathrm{N}$ ratio of $23.40 \pm 0.20$ atom \% (SE, $n=4), 26330 \pm 303 \%$ (SE, $n=4)$ and $6.45 \pm 0.20$ (SE, $n=4$ ), respectively.

To start the experiments, ${ }^{13} \mathrm{C}$-labeled Chlorella spp. were injected into three of the four chambers $(T=0 \mathrm{~h})$ and stirrers mounted $5 \mathrm{~cm}$ beneath the chamber lids were activated to homogeneously distribute the algae over the enclosed sediment surface. Approximately $1.8 \mathrm{~g}$ algal- $\mathrm{C} \mathrm{m}^{-2}$ was added to each experimental chamber except to cores collected at the $\mathrm{KBC}$ site, where $\sim 1.6 \mathrm{~g}$ algal- $\mathrm{C} \mathrm{m}^{-2}$ was added. Ten minutes after the algae were injected; stirrers were switched off for $1 \mathrm{~h}$ to allow the labeled algae to sink to the sediment surface. Stirrers were then turned on and the chamber waters gently mixed (without creating sediment resuspension) at $3 \mathrm{rpm}$ for the remainder of the experiments. Pilot studies 
revealed that stirring at $3 \mathrm{rpm}$ maintained a sufficiently thin diffusive sub-layer $(<1 \mathrm{~mm})$ to ensure that $\mathrm{O}_{2}$ flux into the sediments within each chamber was not diffusion limited. To avoid contaminating the control chamber (used for background isotopic signatures) with labeled algae or labeled dissolved inorganic carbon (DIC), the control chamber was hydraulically (but not thermally) isolated from the water bath with an acrylic chamber.

\subsection{Chamber sampling}

Water samples used to calculate fluxes of oxygen (sediment $\mathrm{O}_{2}$ consumption) and DIC were extracted with a $140 \mathrm{ml}$ syringe from each chamber at $12 \mathrm{~h}$ intervals throughout the duration of each $48 \mathrm{~h}$ study, through stop-cock valves fixed within the chamber lids. Simultaneously, $140 \mathrm{ml}$ of replacement water from a freshly filled, filtered seawater reservoir (maintained at $24^{\circ} \mathrm{C}$ ) was added to each chamber through a second stop-cock mounted downstream of the extraction valve. Two $60 \mathrm{ml}$ samples of chamber water were immediately transferred into gas-tight glass B.O.D. bottles via a $10 \mathrm{~cm}$ tube attached to the syringe nozzle, and fixed for dissolved $\mathrm{O}_{2}$ Winkler analysis. This was followed by a $2 \mathrm{ml}$ water sample, which was passed through a $0.25 \mu \mathrm{m}$ sterile, cellulose acetate filter into gas tight $4 \mathrm{ml}$ borosilicate glass vials (Labco, UK) and fixed with $5 \mu \mathrm{l}$ of $6 \% \mathrm{HgCl}_{2}$ for total $\mathrm{DIC}$ and ${ }^{13} \mathrm{C}$ isotope-ratio mass-spectrometry (IRMS) analyses. Reservoir water that was used as a replacement was also sampled and fixed for $\mathrm{O}_{2}$ and DIC analyses thereby allowing concentrations and flux rates through time to be corrected for dilution effects. After sampling for $\mathrm{O}_{2}$ and DIC and prior to the start of the next incubation, chamber waters were re-oxygenated. Bubbles were then removed from beneath each chamber lid, lids were replaced, new samples for $\mathrm{O}_{2}$ and DIC taken and the incubations continued. Flux rates of $\mathrm{O}_{2}$ (hence SOC) and rates of DIC efflux were calculated from algae amended chambers from linear changes in the concentration of $\mathrm{O}_{2}$ (down to $150 \mu \mathrm{moll}^{-1}$ or $70 \%$ saturation) and DIC through time. The presented SOC data are mean rates $( \pm 1 \mathrm{SE}, n=3$ ) calculated from average SOC rates measured from each algae-amended chamber over each $48 \mathrm{~h}$ experiment.

At the end of each $48 \mathrm{~h}$ experiment, the chambers were removed from the water bath and immediately processed for sedimentary mangrove biomass (SMB), macrofauna and bacterial phospholipid derived fatty acid (PLFA) analyses. Three $6.5 \mathrm{~cm}$ (i.d.) coring tubes were inserted into sediment (one each for SMB, macrofauna and PLFA), removed and the sediment core sample sectioned into $0-2$ and $2-5 \mathrm{~cm}$ sediment slices using an extruder. Sectioned samples for SMB and PLFA were transferred to $50 \mathrm{ml}$ Corning Vials ${ }^{\circledR}$ and prewashed (methanol: dichloromethane in a 1:1 ratio) brown glass bottles, respectively, and frozen at $-20^{\circ} \mathrm{C}$ until analysis. Macrofaunal samples were fixed whole with $4 \%$ buffered formaldehyde seawater.

\subsection{Analysis}

To measure SMB, frozen sediment sub-core samples were thawed, sieved with freshwater on nested $250 \mu \mathrm{m}$ and $1 \mathrm{~mm}$ mesh sieves, the mangrove leaf litter, roots and fibrous material picked out at $150 \times$ magnification under a dissecting microscope and then dried at $35^{\circ} \mathrm{C}$ for 4 days. Dried material was weighed on an electronic balance. As a result of a positive, highly significant correlation between SMB and sediment particulate organic carbon (POC) $(r=0.967$, $P=0.007, n=5$ ) SMB has been used as a readily measured first order proxy for sediment POC content in this study. Sediment characteristics from all sites are shown in Table 1.

Frozen sediment samples for bacterial analysis were freeze dried (with no oil used for sealing) and subsequently ground with a mortar and pestle. Stones were removed using a $500 \mu \mathrm{m}$ mesh sieve, and sediment was ground-up again. Lipids were extracted from approximately $3 \mathrm{~g}$ of dried sediment by a Bligh and Dyer extraction procedure (Middelburg et al., 2000), in which the lipids were sequentially isolated by rinsing on a silicic acid column with chloroform, acetone and methanol. The lipid extract was then derivatized to volatile fatty acid methyl esters (FAME) and measured by gas chromatography isotopic ratio mass spectrometry (GC-IRMS) for PLFA concentration and $\delta^{13} \mathrm{C}$-signatures (Middelburg et al., 2000). The C-isotopic ratios were corrected for the one methyl group inserted during derivatization. Bacterial biomass was measured by GC-IRMS, and bacterial biomass was calculated as PLFA $\left(a i \mathrm{C}_{17: 0}, i \mathrm{C}_{17: 0}\right.$, ai $\mathrm{C}_{15: 0}, i \mathrm{C}_{14: 0}, 10$ Methyl- $\mathrm{C}_{16: 0}$, see Boschker and Middelburg 2002) concentration $(\mu \mathrm{mol}) \mathrm{ml}^{-1}$ sediment/ $(a \times b)$, where $a$ is the average PLFA concentration in bacteria of $0.056 \mathrm{~g} \mathrm{C} \mathrm{PLFA} \mathrm{g}^{-1}$ biomass (Brinch-Iversen and King, 1990), and $b$ is the average fraction-specific bacterial PLFA encountered in sediment dominated by bacteria ( 0.18 ; calculated after Rajendran et al., 1993). The prefixes " $i$ " and "ai" refer to "iso" and "antiso", respectively.

Faunal samples fixed in formaldehyde were gently sieved on a $500 \mu \mathrm{m}$ mesh sieve in cool, filtered seawater in the lab and macrofauna picked out and identified under a dissecting microscope. Organisms were identified to major taxon, with polychaetes and crustaceans identified to the lowest taxonomic level possible. Separate picking utensils were used for unlabeled and labeled samples to avoid contamination with stable isotopes. Single organisms were washed of attached organic debris in cooled, filtered seawater, placed in tin cups and dried at $35-40^{\circ} \mathrm{C}$ for 4 days. Calcareous shelled organisms were decalcified in double boated silver caps using the methods of Sweetman et al. (2009). In order to obtain sufficient biomass for isotope measurements, some individual organisms were combined.

The isotopic ratios $\left({ }^{13} \mathrm{C} /{ }^{12} \mathrm{C}\right)$ and DIC concentration of the chamber water samples were measured against a lithium carbonate standard (calibrated against NIST 8545) using a PDZ Europa 20-20 IRMS, coupled with a Poroplot-Q GC column 
Table 1. Summary of sediment characteristics (averaged over top $5 \mathrm{~cm}$ of sediment) from single un-amended cores collected at all 5 sites. Water content was determined by weight loss upon drying at $60^{\circ} \mathrm{C}$ and total $\mathrm{C}$ and $\mathrm{N}$ were measured by CHN analysis (Middelburg et al., 2000). POC was analyzed by CHN analysis following acidification to remove inorganic C as in Middelburg et al. (2000).

\begin{tabular}{llllllll}
\hline Site & $\begin{array}{l}\text { Density } \\
(\mathrm{g} / \mathrm{ml})\end{array}$ & $\begin{array}{l}\text { Water } \\
\text { content }(\%)\end{array}$ & $\begin{array}{l}\text { SMB } \\
\left(\mathrm{g} \mathrm{dw} \mathrm{m}^{-2}\right)\end{array}$ & Total C (\%) & POC (\%) & Total N (\%) & C: N \\
\hline PHM & 1.13 & 38.54 & 1998.01 & 8.75 & 8.22 & 0.44 & 22.13 \\
PHR & 1.23 & 45.88 & 699.15 & 3.44 & 3.05 & 0.20 & 18.24 \\
PHC & 1.72 & 31.79 & 0 & 2.44 & 0.52 & 0.04 & 16.58 \\
KBR & 1.52 & 27.03 & 599.70 & 1.09 & 0.91 & 0.07 & 16.51 \\
KBC & 1.73 & 33.36 & 0 & 8.20 & 0.49 & 0.04 & 14.79 \\
\hline
\end{tabular}

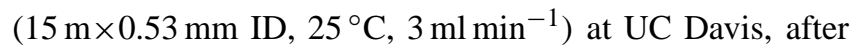
acidification with $1 \mathrm{ml}$ of $85 \%$ phosphoric acid. The isotopic measurements and biomass of macrofauna organisms were measured using both Europa Integra (enriched isotopes) and Hydra 20/20 (natural isotopes) isotope ratio mass spectrometers at UC Davis, USA. The total amount of $\mathrm{DI}^{13} \mathrm{C}$ produced from the added tracer $\left(\mathrm{mmol}{ }^{13} \mathrm{C} \mathrm{m}^{-2}\right)$ was calculated as the product of excess ${ }^{13} \mathrm{C}(E)$ (expressed as atom $\%{ }^{13} \mathrm{C}$ ) and the total DIC concentration, and subsequently converted to $\mathrm{mg}{ }^{13} \mathrm{Cm}^{-2}$. $E$ is the difference between the labeled fraction $F$ of a sample and the background sampled from the un-amended control chamber:

$E=F_{\text {sample }}-F_{\text {background }}$

where

$F={ }^{13} \mathrm{C} /\left({ }^{13} \mathrm{C}+{ }^{12} \mathrm{C}\right)=R /(R+1)$

and

$R=\left(\delta^{13} \mathrm{C} / 1,000+1\right) \times R_{\mathrm{VPDB}}$

where $R_{\mathrm{VPDB}}=0.0112372$.

Uptake of ${ }^{13} \mathrm{C}$ after $48 \mathrm{~h}$ by macrofauna $\left(\mathrm{mg}{ }^{13} \mathrm{C} \mathrm{m}^{-2}\right.$ ) was calculated as the product of the excess ${ }^{13} \mathrm{C}$ and $\mathrm{C}$-content in the animal (expressed as unit weight). If 'background' samples of certain taxa were unavailable in the control chamber for calculating ${ }^{13} \mathrm{C}$-uptake, $E$ was calculated using background $F$-values from closely related organisms or from fauna within the same feeding guild. Polychaete feeding modes were determined from Fauchald and Jumars (1979). For bacteria, total uptake $\left(\mathrm{mg}{ }^{13} \mathrm{Cm}^{-2}\right)$ of ${ }^{13} \mathrm{C}(U)$ after $48 \mathrm{~h}$ was calculated according to Moodley et al. (2000) from label incorporation into bacterial fatty acids $\left(a i \mathrm{C}_{17: 0}, i \mathrm{C}_{17: 0}\right.$, ai $\mathrm{C}_{15: 0}, i \mathrm{C}_{14: 0}, 10$ Methyl- $\mathrm{C}_{16: 0}$, Boschker and Middelburg 2002) as:

$U_{\text {bact }}=\Sigma_{\text {bact fatty acids }} /(a \times b)$

To calculate the daily production rate of DIC $\left(\mathrm{mg} \mathrm{C} \mathrm{m}^{-2} \mathrm{~d}^{-1}\right)$ from the added tracer, the amount of $\mathrm{DI}^{13} \mathrm{C}$ produced $\left(\mathrm{mg}^{13} \mathrm{C} \mathrm{m}^{-2}\right)$ was divided by 2 , and adjusted to account for the fractional abundance of ${ }^{13} \mathrm{C}$ in the added algae as:

DIC produced $\mathrm{d}^{-1}=\mathrm{DI}^{13} \mathrm{C}$ produced $\mathrm{d}^{-1} /$

fractional abundance of ${ }^{13} \mathrm{C}$ in algae

DIC produced $\mathrm{d}^{-1}$ refers to only the DIC derived from the added microalgal-C. Total C-uptake per day $\left(\mathrm{mg} \mathrm{C} \mathrm{m}^{-2} \mathrm{~d}^{-1}\right)$ by fauna and bacteria was calculated from faunal and bacterial ${ }^{13} \mathrm{C}$-uptake data in the same way. The amount of algal-C added to each experiment contributed only $0.2-2 \%$ to the Cstanding stock in the top $5 \mathrm{~cm}$ of sediment $\left(85-929 \mathrm{~g} \mathrm{C} \mathrm{m}^{-2}\right.$, based on data in Table 1). Nevertheless, because different amounts of algal-C were added to the KBC study compared to all the other experiments as previously stated, total daily DIC efflux, daily DIC production from added algal-C and $\mathrm{C}$-uptakes rates by fauna and bacteria have been normalized by the amount of algal- $\mathrm{C}$ added $\left(\mathrm{g} \mathrm{C} \mathrm{m}^{-2}\right)$. As such, all DIC production and C-uptake rates are given in units of $\mathrm{mgg} \mathrm{C} \mathrm{m}{ }^{-2} \mathrm{~d}^{-1}$.

\subsection{Statistics}

Because of seasonal differences in temperature when the Pearl Harbor and Kaneohe Bay sites were sampled, as well as potential artefacts from dissimilarities in tidal elevation affecting comparisons between locations (e.g. subtidal vs. intertidal characteristics and processes quantified using sediments from Pearl Harbor and Kaneohe Bay sites, respectively), differences among variables between Pearl Harbor sites were analysed separately from those in Kaneohe Bay using a one-way ANOVA test followed by a Tukey posthoc test. Differences in variables between the KBR and $\mathrm{KBC}$ sites were analysed by parametric t-tests. Prior to statistical analysis, data were checked for normality and heteroscedasticity. A square-root transformation was applied, when necessary, to obtain homogeneity of variances. If data sets failed to meet ANOVA assumptions after transformation, a non-parametric Kruskal-Wallis test was performed. Correlations among variables were analysed by Pearson Product Moment correlations, after initially checking for linearity 

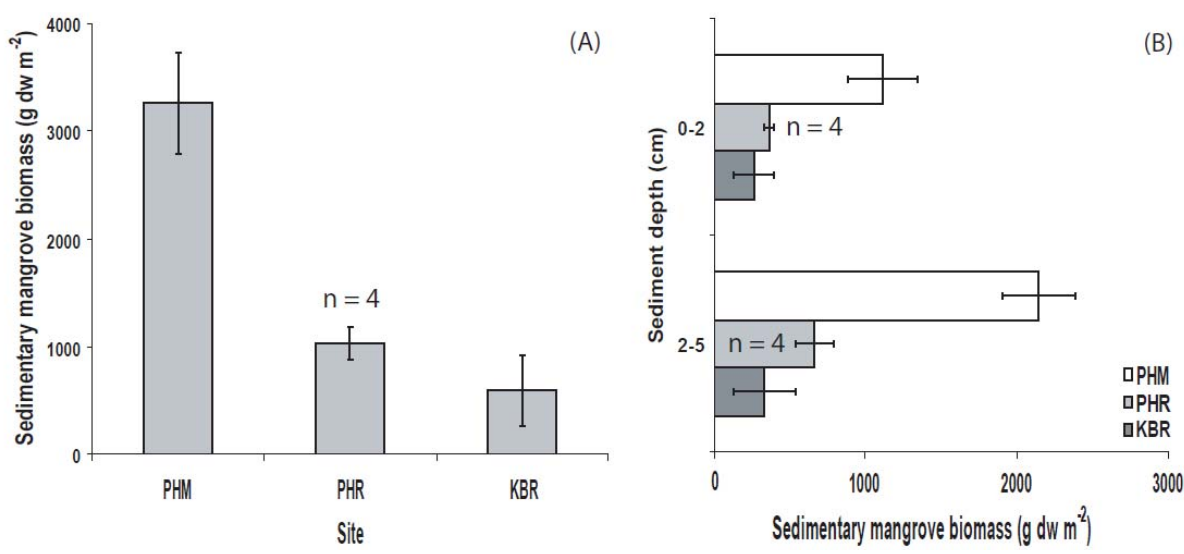

Fig. 2. Total sedimentary mangrove biomass (A) and vertical distribution of sedimentary mangrove biomass (B) within cores from the PHM, PHR and KBR sites. Bars denote mean \pm 1 SE $(n=3)$, unless otherwise stated.

and bi-variate normality of correlation data and applying a square root transform, if necessary (Zar, 1999). An $\alpha$-level of 0.05 was chosen as the criterion for statistical significance. All data was analysed using Sigma-Stat (Version 3.5, Systat) software.

\section{Results}

\subsection{Sedimentary mangrove biomass}

Leaf material was only found at the sediment surface in cores collected from the PHM site. SMB was significantly lower (by 60\%) in sediment cores from the PHR compared to the PHM site $(P=0.003$, Fig. $2 \mathrm{a})$. This equates to a SMB loss rate of $\sim 36 \% \mathrm{yr}^{-1}$ assuming that the SMB in the original mangrove stand at the PHR location averaged $3550 \mathrm{~g} \mathrm{dw} \mathrm{m}^{-2}$ as found by Demopoulos and Smith (2010) (Fig. 2a). SMB in sediment cores from the KBR site (Fig. 2a) was reduced by approximately $70 \%$ after 6 -yr (decomposition rate of $12 \% \mathrm{yr}^{-1}$ ) assuming SMB down to $5 \mathrm{~cm}$ depth in the original mangrove forest at the KBR site was approximately $2000 \mathrm{~g} \mathrm{dw} \mathrm{m}^{-2}$ as found by Demopoulos (2004). Mean SMB increased with sediment depth in cores from all sites (Fig. 2b). No SMB was found in sediment cores from either the PHC or KBC sampling locations.

\subsection{Benthic biotic structure}

Macrofauna abundance and biomass from Pearl Harbor were significantly different between sites ( $P=0.014$ and $P=0.012$, respectively), with greater abundance $\left(183427 \pm 48081 \mathrm{~m}^{-2}, \mathrm{SE}, n=3\right)$ and biomass (3391 $\pm 646 \mathrm{mg} \mathrm{C} \mathrm{m}^{-2}$, SE, $n=3$ ) in sediment cores from the PHR site compared to the PHM and PHC locations (Figs. 3a and c, Table 2). Mean macrofauna abundance and biomass in sediment collected from the PHR and PHC sites was higher in the top $2 \mathrm{~cm}$ of sediment compared to the bottom sediment layer (Fig. 3b and d). Bacterial biomass was significantly higher $(P=0.010)$ in sediment cores from the PHM site (18 154 $\pm 2004 \mathrm{mg} \mathrm{C} \mathrm{m}^{-2}$, range, $\left.n=2\right)$ compared to the other Pearl Harbor locations (Fig. 3e). Mean bacterial biomass was higher in surficial sediments in cores from both the PHM and PHR sites (Fig. 3f). In Kaneohe Bay, faunal abundance estimates were significantly higher $(P=0.003$, Fig. 4a) in sediments from the KBR $\left(46610 \pm 3957 \mathrm{~m}^{-2}\right.$, SE, $n=3)$ compared to the KBC site $\left(18684 \pm 1517 \mathrm{~m}^{-2}\right.$, SE, $n=3$ ), but despite higher mean faunal biomass being found in sediment cores from the KBR site (Fig. 4c, Table 2), no significant difference in faunal biomass between the two sites could be detected $(P=0.146)$. Mean faunal abundances in sediments collected from the KBR and KBC sites, as well as mean faunal biomass in cores from the KBR site, decreased with sediment depth (Fig. $4 \mathrm{~b}$ and d). The same pattern was found for mean bacterial biomass, which was higher in surficial sediments in cores collected from both Kaneohe Bay sites (Fig. 4f). Total bacterial biomass was significantly higher in sediments recovered from the KBR compared to the $\mathrm{KBC}$ site $(P=0.036$, Fig. $4 \mathrm{e})$.

\subsection{Macrofauna community structure}

Sub-surface deposit feeding tubificid oligochaetes dominated macrofauna abundance (83\%) and biomass $(80 \%)$ in cores collected at the PHM location, whereas surface feeding spionid polychaetes were more dominant in terms of abundance (37\%) and biomass (34\%) in sediments from the PHR site (Table 2). Harpacticoid copepods were the most abundant taxon in sediment cores from the PHC site (32\%), but spionid polychaetes accounted for the major part of the biomass (62\%). Surface-feeding corophiids completely dominated the amphipod taxa in sediment samples from the KBR site and contributed most to abundance $(62 \%)$ and biomass $(80 \%)$ in cores collected from this site, but surface feeding sabellid polychaetes were more important in 

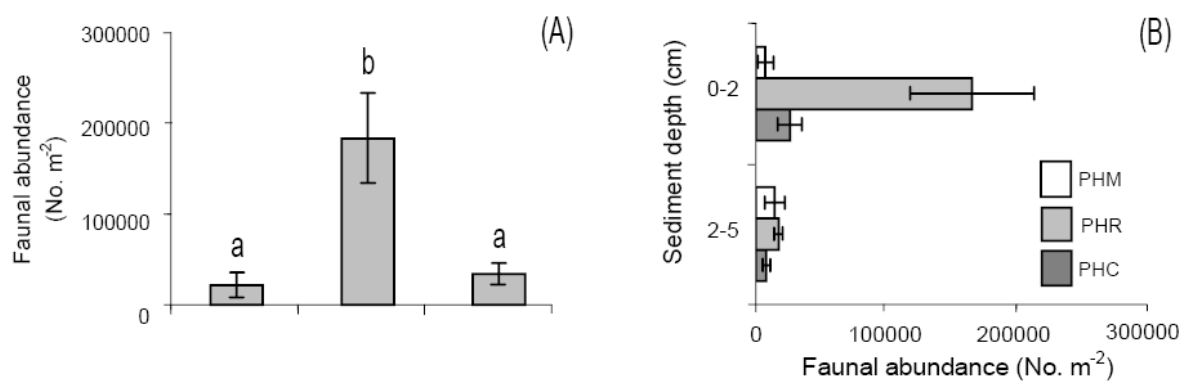

(B)
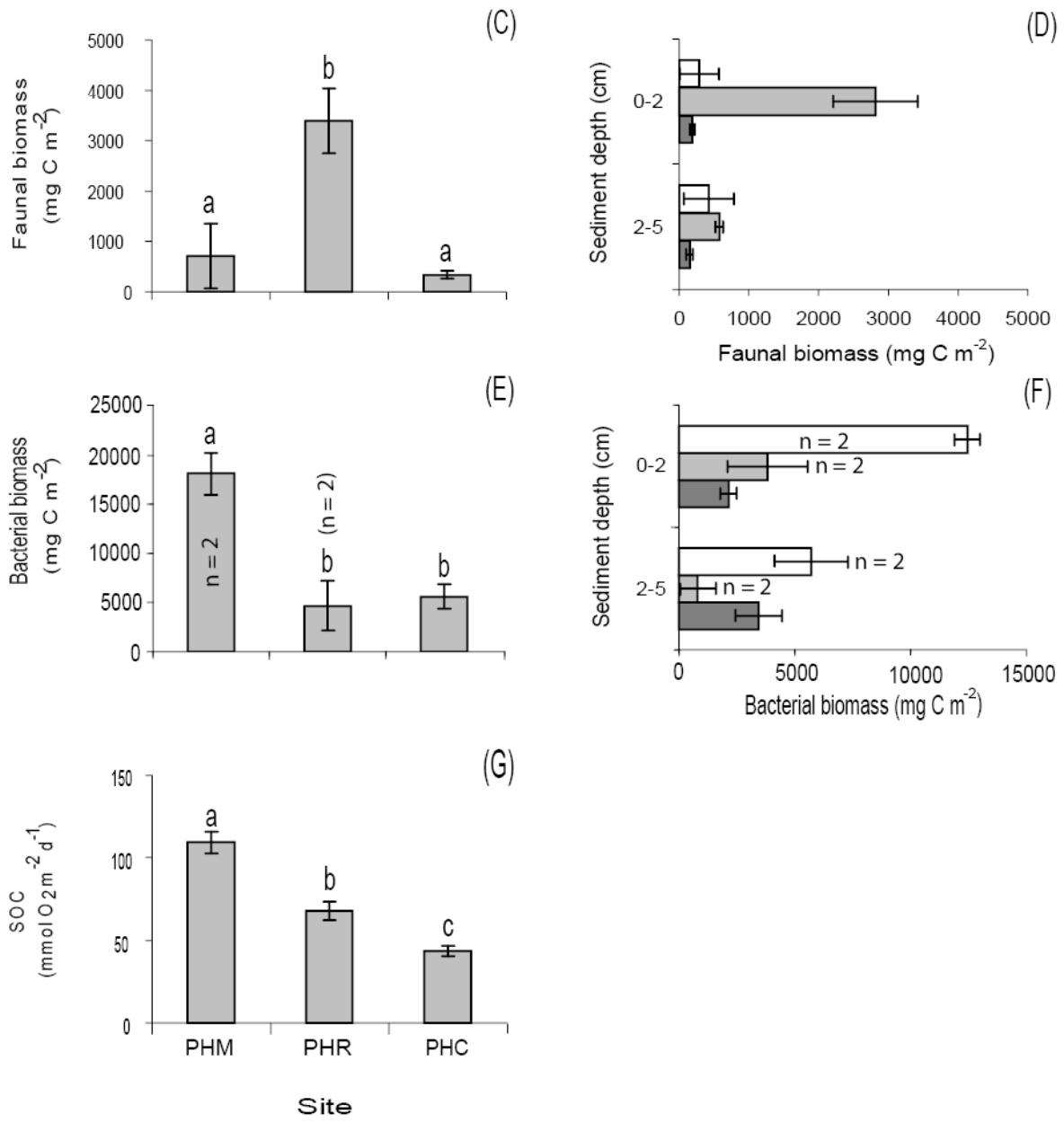

Fig. 3. Total and vertical distribution of macrofauna abundance (A and $\mathbf{B}$, respectively), biomass $(\mathbf{C}$ and $\mathbf{D}$, respectively), and bacterial biomass (E and $\mathbf{F}$, respectively) in cores from all Pearl Harbor sites. Sediment oxygen consumption rates in cores from all Pearl Harbor sites is shown in $(\mathbf{G})$. Significant differences $(P<0.05)$ in parameters between sites are designated by different letters. Error bars denote \pm 1 SE $(n=3)$, unless $n=2$, where error bars denote \pm range of two samples because of insufficient sample for PLFA analysis from a 3rd replicate chamber.

terms of abundance $(45 \%)$ in cores recovered from the $\mathrm{KBC}$ site (Table 2). Spionid polychaetes as well as unidentified taxa (i.e. poorly preserved fauna) contributed more to faunal biomass (31\% and 30\%, respectively) in sediments sampled at the $\mathrm{KBC}$ site (Table 2).

\subsection{Sediment oxygen consumption (SOC)}

SOC in algae-amended cores was significantly different between sites in Pearl Harbor $(P<0.001)$, with greater SOC rates for sediments from the PHM and PHR sites compared to the PHC site (Fig. 3g). Significantly higher SOC rates were also found in the PHM experiments compared to the PHR study (Fig. 3g). In the Kaneohe Bay experiments, SOC 

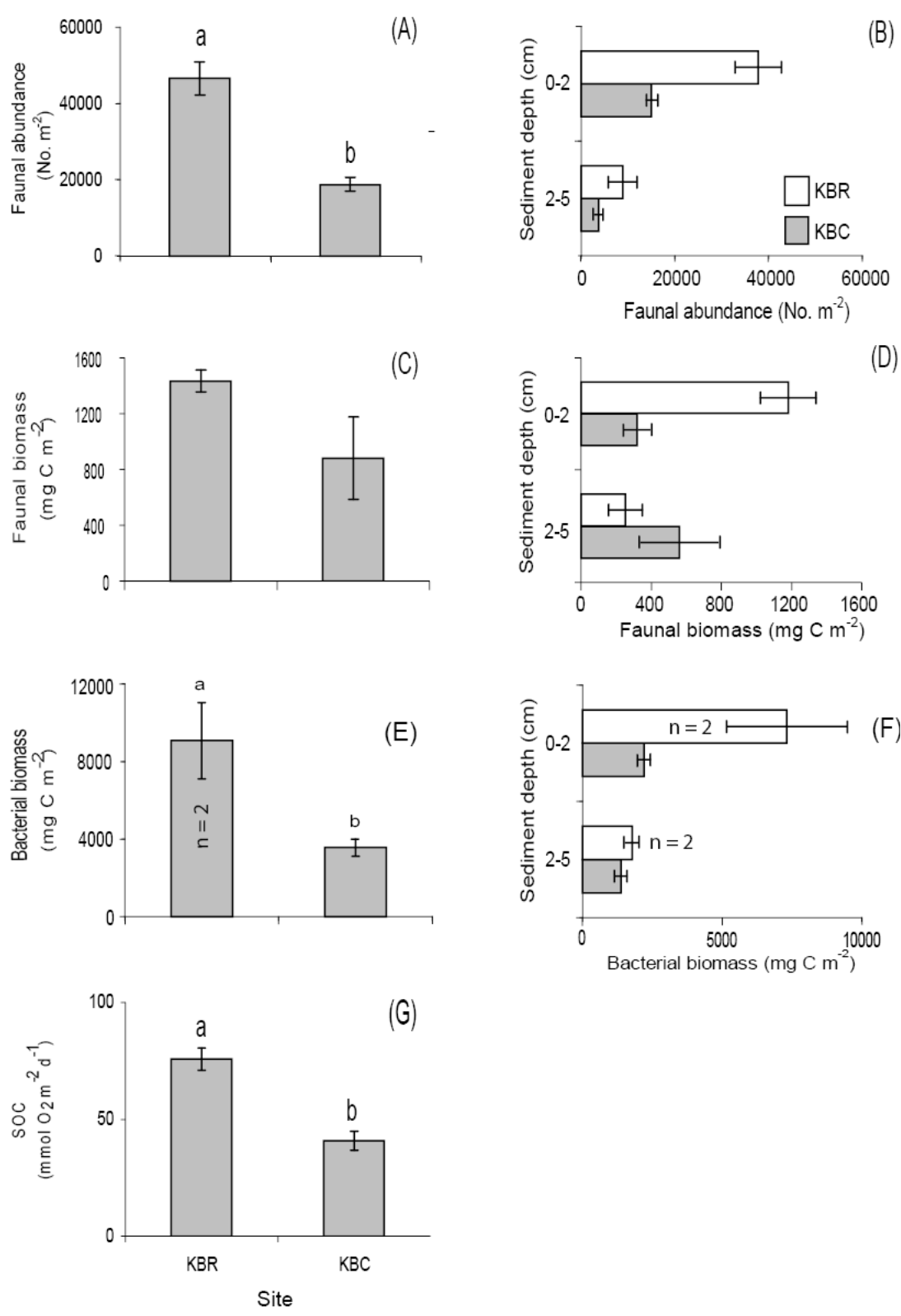

(D)

Fig. 4. Total and vertical distribution of macrofauna abundance (A and $\mathbf{B}$, respectively), biomass ( $\mathbf{C}$ and $\mathbf{D}$, respectively), and bacterial biomass ( $\mathbf{E}$ and $\mathbf{F}$, respectively) in cores from all Kaneohe Bay sites. Sediment oxygen consumption rates in cores from all Kaneohe Bay sites is shown in $(\mathbf{G})$. Significant differences $(P<0.05)$ in parameters between sites are designated by different letters. Error bars denote \pm 1 SE $(n=3)$ unless $n=2$, where error bars denote \pm range of two samples because of insufficient sample for PLFA analysis from a 3rd replicate chamber.

was greater in the KBR experiments compared to the Kaneohe Bay control $(P=0.005$, Fig. $4 \mathrm{~g})$. SOC was strongly correlated with both total benthic (macrofauna and bacteria) biomass ( $r=0.876, P=0.0002, n=12$, Fig. 5$)$ as well as SMB ( $r=0.901, P<0.0001, n=13$, Fig. 6$)$.

\subsection{DIC production and C-uptake from added algae}

Between 71 and $90 \%$ of the processed algal-C was found in the DIC pool after $48 \mathrm{~h}$ (Table 3 ), and the mean daily production rate of DIC from algal-C accounted for between 4$12 \%$ of the mean total daily DIC efflux rate in all studies, assuming a molar mass weight for $\mathrm{C}$ of 12 (Table 3). Production of DIC from added algal-C was significantly different between Pearl Harbor sites ( $P=0.011)$, with production 
Table 2. Mean abundance (Number $\mathrm{m}^{-2} \pm 1 \mathrm{SE}, n=3$ ) and biomass ( $\mathrm{mg} \mathrm{C} \mathrm{m}{ }^{-2} \pm 1 \mathrm{SE}, n=3$ ) estimates of major macrofauna taxa from sediment cores collected from all 5 sites. Star $\left(^{*}\right)$ denotes mean \pm range of 2 samples when a single replicate sample was lost prior to biomass analysis. Total macrofauna abundance (Number $\mathrm{m}^{-2} \pm 1 \mathrm{SE}, n=3$ ) and biomass $\left(\mathrm{mg} \mathrm{C} \mathrm{m}^{-2} \pm 1 \mathrm{SE}, n=3\right)$ is also shown.

\begin{tabular}{|c|c|c|c|c|c|c|c|c|c|c|}
\hline \multirow[b]{2}{*}{ Taxon } & \multicolumn{2}{|c|}{ PHM } & \multicolumn{2}{|c|}{ PHR } & \multicolumn{2}{|c|}{ PHC } & \multicolumn{2}{|c|}{ KBR } & \multicolumn{2}{|c|}{$\mathrm{KBC}$} \\
\hline & $\begin{array}{l}\text { Abundance } \\
\left(\text { No. }^{-2} \text { ) }\right.\end{array}$ & $\begin{array}{l}\text { Biomass } \\
\left(\mathrm{mg} \mathrm{C} \mathrm{m}^{-2}\right)\end{array}$ & $\begin{array}{l}\text { Abundance } \\
\left(\text { No. } \mathrm{m}^{-2} \text { ) }\right.\end{array}$ & $\begin{array}{l}\text { Biomass } \\
\left(\mathrm{mg} \mathrm{C} \mathrm{m}^{-2}\right)\end{array}$ & $\begin{array}{l}\text { Abundance } \\
\left(\text { No. }^{-2}\right)\end{array}$ & $\begin{array}{l}\text { Biomass } \\
\left(\mathrm{mg} \mathrm{C} \mathrm{m}^{-2}\right)\end{array}$ & $\begin{array}{l}\text { Abundance } \\
\left(\text { No. }^{-2} \text { ) }\right.\end{array}$ & $\begin{array}{l}\text { Biomass } \\
\left(\mathrm{mg} \mathrm{C} \mathrm{m}^{-2}\right)\end{array}$ & $\begin{array}{l}\text { Abundance } \\
\left(\text { No. }^{-2} \text { ) }\right.\end{array}$ & $\begin{array}{l}\text { Biomass } \\
\left(\mathrm{mg} \mathrm{C} \mathrm{m}^{-2}\right)\end{array}$ \\
\hline Oligochaeta & & & & & & & $8036 \pm 2400$ & $155 \pm 29$ & $402 \pm 266$ & $8 \pm 5$ \\
\hline Enchytraeidea & & & $3114 \pm 1480$ & $75 \pm 33$ & & & & & & \\
\hline Tubificidae & $17981 \pm 10748$ & $572 \pm 510$ & $2411 \pm 1595$ & $55 \pm 40$ & $904 \pm 460$ & $9 \pm 3$ & & & & \\
\hline \multicolumn{11}{|l|}{ Polychaeta } \\
\hline Cirratulidae & & & $29232 \pm 26978$ & $525 \pm 475$ & & & & & $301 \pm 174$ & $8 \pm 5$ \\
\hline Chaetopteridae & & & & & & & & & $201 \pm 100$ & $28 \pm 14$ \\
\hline Opheliidae & & & $9242 \pm 958$ & $71 \pm 15$ & $904 \pm 522$ & $35 \pm 34$ & & & $1205 \pm 522$ & $38 \pm 1 *$ \\
\hline Syllidae & & & & & & & & & $201 \pm 201$ & $4 \pm 4$ \\
\hline Lumbrineridae & & & & & & & & & $2913 \pm 559$ & $103 \pm 28$ \\
\hline Capitellidae & $2813 \pm 2362$ & $107 \pm 98 *$ & $5324 \pm 1282$ & $381 \pm 86$ & $502 \pm 502$ & $6 \pm 6$ & $2210 \pm 822$ & $47 \pm 20$ & $201 \pm 100$ & $4 \pm 3$ \\
\hline Eunicidae & & & & & & & & & $100 \pm 100$ & $43 \pm 43$ \\
\hline Sabellidae & & & $37871 \pm 21799$ & $239 \pm 136$ & $3214 \pm 1222$ & $28 \pm 11$ & & & $8538 \pm 266$ & $96 \pm 5$ \\
\hline Spionidae & & & $68911 \pm 23656$ & $1111 \pm 337$ & $8237 \pm 2147$ & $208 \pm 62$ & $201 \pm 201$ & $29 \pm 29$ & $1708 \pm 402$ & $265 \pm 65$ \\
\hline \multicolumn{11}{|l|}{ Crustacea } \\
\hline Amphipoda & & & $4520 \pm 3175$ & $65 \pm 53$ & & & $28529 \pm 2861$ & $1138 \pm 143$ & $1607 \pm 402$ & $29 \pm 9$ \\
\hline Decapoda & & & $201 \pm 100$ & $651 \pm 354$ & & & & & & \\
\hline Harpacticoida & & & $11853 \pm 4111$ & $15 \pm 2$ & $10648 \pm 4133$ & $13 \pm 5$ & & & & \\
\hline Isopoda & & & & & & & $100 \pm 100$ & $1 \pm 1$ & & \\
\hline Ostracoda & & & $1005 \pm 1005$ & $6 \pm 6$ & & & $5625 \pm 2032$ & $21 \pm 8$ & $100 \pm 100$ & $1 \pm 1$ \\
\hline Tanaidacea & & & & & & & $1607 \pm 1317$ & $23 \pm 20$ & & \\
\hline \multicolumn{11}{|l|}{ Mollusca } \\
\hline Gastropoda & & & $100 \pm 100$ & $10 \pm 10$ & & & & & & \\
\hline Nematoda & & & $8538 \pm 3688$ & $26 \pm 18$ & $9643 \pm 3595$ & $14 \pm 4$ & $301 \pm 174$ & $\ldots$ & $502 \pm 362$ & $1 \pm 1^{*}$ \\
\hline Nemertea & & & & & & & & & $100 \pm 100$ & $1 \pm 1$ \\
\hline Unknown & $804 \pm 804$ & $69 \pm 62$ & $1105 \pm 703$ & $161 \pm 40$ & $100 \pm 100$ & $24 \pm 13$ & $\ldots$ & $20 \pm 18$ & $603 \pm 301$ & $266 \pm 207$ \\
\hline Total & $21597 \pm 12731$ & $713 \pm 639$ & $183427 \pm 48081$ & $3391 \pm 646$ & $34154 \pm 10463$ & $337 \pm 74$ & $46610 \pm 3957$ & $1435 \pm 77$ & $18684 \pm 1517$ & $882 \pm 297$ \\
\hline
\end{tabular}

being significantly lower in the PHC experiments compared to the other Pearl Harbor studies (Fig. 7a). No significant difference in the amount of DIC produced from algal$\mathrm{C}$ could be detected between the KBR and $\mathrm{KBC}$ experiments ( $P=0.250$, Fig. 8a). On average, macrofauna in the PHR and both control site experiments took up approximately 1.6-3.8 times as much algal-C as the bacteria (Table 3 ). These patterns contrasted with the benthic response observed in the PHM and KBR experiments, where mean bacteria C-uptake rates were approximately 15.3 and 1.4 times greater than for the macrofauna, respectively (Table 3). Short-term C- uptake rates by macrofauna were significantly different between Pearl Harbor sites $(P<0.001$, Fig. $7 \mathrm{~b})$, with significantly higher faunal $\mathrm{C}$-uptake rates measured in the PHR compared to the PHM and PHC experiments. Mean faunal $\mathrm{C}$-uptake rates were also significantly higher in experiments using sediment cores recovered from the KBR compared to the KBC site ( $P=0.003$, Fig. 8 b). Mean uptake of algal-C by macrofauna was highest in the top-most sediment layer in the PHR, PHC, KBR and KBC experiments (Figs. 7c and 8c). Surface-feeding spionid polychaetes and corophiid amphipods in sediments from the PHR and KBR sites took up 
Table 3. Mean rate $\left(\mathrm{mg} \mathrm{g} \mathrm{C}^{-1} \mathrm{~m}^{-2} \mathrm{~d}^{-1} \pm 1 \mathrm{SE}, n=3\right)$ and percentage $( \pm 1 \mathrm{SE}, n=3)$ of DIC production, faunal C-uptake and bacterial C-uptake from added algal-C in experiments from all 5 sites. Total amount of $\mathrm{C}$ processed $\mathrm{d}^{-1}\left(\mathrm{mg} \mathrm{g} \mathrm{C}^{-1} \mathrm{~m}^{-2} \mathrm{~d}^{-1} \pm 1 \mathrm{SE}, n=3\right)$ and the percentage of total added $\mathrm{C}$ which was processed is also shown. Numbers in bold denote mean total daily DIC efflux normalized to algal-C $\left(\mathrm{mg} \mathrm{g} \mathrm{C}-1 \mathrm{~m}^{-2} \mathrm{~d}^{-1} \pm 1 \mathrm{SE}, n=3\right)$ and were calculated using a molar mass weight for $\mathrm{C}$ of 12 . Star $\left(^{*}\right)$ denotes mean \pm range of 2 samples when there was insufficient water or sediment sample for accurate DIC and PLFA measurements from a 3rd replicate chamber.

\begin{tabular}{|c|c|c|c|c|c|c|c|c|c|c|}
\hline \multirow[t]{2}{*}{ Site } & \multicolumn{2}{|c|}{ PHM } & \multicolumn{2}{|c|}{ PHR } & \multicolumn{2}{|l|}{ PHC } & \multicolumn{2}{|l|}{ KBR } & \multicolumn{2}{|l|}{ KBC } \\
\hline & Rate & $\%$ & Rate & $\%$ & Rate & $\%$ & Rate & $\%$ & Rate & $\%$ \\
\hline DIC & $130.94 \pm 3.17$ & $90.09 \pm 2.98^{*}$ & $128.38 \pm 3.47 *$ & $75.13 \pm 5.87^{*}$ & $92.05 \pm 8.55$ & $88.37 \pm 1.86$ & $127.08 \pm 17.85^{*}$ & $70.75 \pm 5.84 *$ & $147.01 \pm 3.36$ & $89.41 \pm 1.43$ \\
\hline & $(3149.86 \pm 1159.26)$ & & $(1981.89 \pm 496.86)^{*}$ & & $(2840.77 \pm 898.48)$ & & $(1092.24 \pm 674.89)^{*}$ & & $(1914.99 \pm 970.08)$ & \\
\hline Macrofauna & $0.87 \pm 0.64$ & $0.83 \pm 0.56^{*}$ & $39.05 \pm 7.04$ & $19.09 \pm 2.64 *$ & $7.55 \pm 1.89$ & $7.18 \pm 1.73$ & $21.58 \pm 0.63$ & $11.76 \pm 0.75^{*}$ & $12.51 \pm 1.32$ & $7.62 \pm 0.86$ \\
\hline Bacteria & $13.34 \pm 4.41^{*}$ & $9.08 \pm 2.42^{*}$ & $10.20 \pm 6.06^{*}$ & $5.78 \pm 3.23^{*}$ & $4.64 \pm 0.42$ & $4.45 \pm 0.14$ & $30.73 \pm 7.27^{*}$ & $17.49 \pm 5.09^{*}$ & $4.86 \pm 1.24$ & $2.96 \pm 0.77$ \\
\hline $\begin{array}{l}\text { Total amount } \\
\text { processed } d^{-1}\end{array}$ & $144.17 \pm 10.27 *$ & & $171.57 \pm 8.80^{*}$ & & $104.24 \pm 9.75$ & & $178.77 \pm 10.47^{*}$ & & $164.37 \pm 1.23$ & \\
\hline $\begin{array}{l}\% \text { of total amount } \\
\text { of added } \mathrm{C} \text { processed }\end{array}$ & $14.42 \pm 1.03^{*}$ & & $17.16 \pm 0.88^{*}$ & & $10.42 \pm 0.97$ & & $17.88 \pm 1.05^{*}$ & & $16.44 \pm 0.12$ & \\
\hline
\end{tabular}

Table 4. Mean C-uptake rate $\left(\mathrm{mg} \mathrm{g} \mathrm{C}^{-1} \mathrm{~m}^{-2} \mathrm{~d}^{-1} \pm 1 \mathrm{SE}, n=3\right)$ and mean C-uptake rate normalized to biomass $\left(\mathrm{mg} \mathrm{g} \mathrm{C}^{-1} \mathrm{~m}^{-2} \mathrm{~d}^{-1} \mathrm{mg}^{-}\right.$ $\mathrm{C}$ biomass $^{-1} \pm 1 \mathrm{SE}, n=3$ ) of major macrofauna taxa from sediments collected from all 5 sites. Star $\left(^{*}\right)$ denotes mean \pm range of 2 samples when only 2 replicate chambers contained a specific taxon for C-uptake analysis.

\begin{tabular}{|c|c|c|c|c|c|c|c|c|c|c|}
\hline \multirow[b]{2}{*}{ Taxon } & \multicolumn{2}{|r|}{ PHM } & \multicolumn{2}{|r|}{ PHR } & \multicolumn{2}{|r|}{ PHC } & \multicolumn{2}{|r|}{ KBR } & \multicolumn{2}{|r|}{$\mathrm{KBC}$} \\
\hline & C-uptake rate & $\begin{array}{l}\text { C-uptake rate } \\
\text { biomass }^{-1}\left(\times 10^{-6}\right)\end{array}$ & C-uptake rate & $\begin{array}{l}\text { C-uptake rate } \\
\text { biomass }^{-1}\left(\times 10^{-6}\right)\end{array}$ & C-uptake rate & $\begin{array}{l}\text { C-uptake rate } \\
\text { biomass }^{-1}\left(\times 10^{-6}\right)\end{array}$ & C-uptake rate & $\begin{array}{l}\text { C-uptake rate } \\
\text { biomass }^{-1}\left(\times 10^{-6}\right)\end{array}$ & C-uptake rate & $\begin{array}{l}\text { C-uptake rate } \\
\text { biomass }^{-1}\left(\times 10^{-6}\right)\end{array}$ \\
\hline Oligochaeta & $0.71 \pm 0.59$ & $28320 \pm 17484$ & $0.12 \pm 0.05$ & $2890 \pm 1210$ & $0.09 \pm 0.07 *$ & $10100 \pm 8966^{*}$ & $0.07 \pm 0.02$ & $1698 \pm 337$ & 0.03 & 2700 \\
\hline \multicolumn{11}{|l|}{ Polychaeta } \\
\hline Cirratulidae & & & $3.87 \pm 3.54$ & $16155 \pm 676$ & & & & & $0.23 \pm 0.05^{*}$ & $19963 \pm 4008^{*}$ \\
\hline Chaetopteridae & & & & & & & & & $1.08 \pm 0.06^{*}$ & $25645 \pm 2990^{*}$ \\
\hline Opheliidae & & & $1.86 \pm 0.22$ & $64693 \pm 6305$ & $2.38 \pm 2.18^{*}$ & $78324 \pm 4791 *$ & & & $2.57 \pm 0.61^{*}$ & $170784 \pm 2312 *$ \\
\hline Syllidae & & & & & & & & & 0.01 & 812 \\
\hline Lumbrineridae & & & & & & & & & $0.15 \pm 0.07$ & $3759 \pm 1504$ \\
\hline Capitellidae & $0.08 \pm 0.04$ & $7162 \pm 1433$ & $0.40 \pm 0.06$ & $8491 \pm 2681$ & 0.19 & 13509 & $0.38 \pm 0.11$ & $32882 \pm 7270$ & $0.07 \pm 0.07^{*}$ & $21783 \pm 21629 *$ \\
\hline Eunicidae & & & & & & & & & 0.69 & 5400 \\
\hline Sabellidae & & & $5.78 \pm 3.20$ & $37429 \pm 7678$ & $0.66 \pm 0.22$ & $33430 \pm 8863$ & & & $4.58 \pm 0.09$ & $106739 \pm 12140$ \\
\hline Spionidae & & & $21.58 \pm 3.29$ & $89580 \pm 8991$ & $3.88 \pm 1.41$ & $98746 \pm 27840$ & 1.66 & 19051 & $2.41 \pm 0.64$ & $75999 \pm 19842$ \\
\hline \multicolumn{11}{|l|}{ Crustacea } \\
\hline Amphipoda & & & $0.88 \pm 0.71$ & $25406 \pm 12337$ & & & $20.01 \pm 1.47$ & $350789 \pm 39778$ & $1.00 \pm 0.38$ & $42316 \pm 10923$ \\
\hline Decapoda & & & $3.37 \pm 1.08^{*}$ & $7952 \pm 4186^{*}$ & & & & & & \\
\hline Harpacticoida & & & $0.11 \pm 0.04$ & $7909 \pm 3137$ & $0.33 \pm 0.17$ & $17859 \pm 8881$ & & & & \\
\hline Isopoda & & & & & & & 0.03 & 6021 & & \\
\hline Ostracoda & & & 0.06 & 3367 & & & $0.01 \pm 0.00$ & $1083 \pm 274$ & 0.00 & 99 \\
\hline Tanaidacea & & & & & & & $0.21 \pm 0.19^{*}$ & $4977 \pm 1471^{*}$ & & \\
\hline \multicolumn{11}{|l|}{ Mollusca } \\
\hline Gastropoda & & & 0.29 & 9754 & & & & & & \\
\hline Nematoda & & & $0.11 \pm 0.09$ & $4589 \pm 998$ & $0.18 \pm 0.17$ & $9292 \pm 8048$ & & & & \\
\hline Nemertea & & & & & & & & & 0.07 & 22625 \\
\hline Unknown & $0.13 \pm 0.00^{*}$ & $15790 \pm 8841 *$ & $1.97 \pm 0.60$ & $48201 \pm 16425$ & $0.79 \pm 0.59$ & $49322 \pm 25730$ & $0.62 \pm 0.49^{*}$ & $40260 \pm 5619^{*}$ & $1.48 \pm 0.88$ & $55884 \pm 29258$ \\
\hline
\end{tabular}


more microalgal- $\mathrm{C}$ in $48 \mathrm{~h}$ than any other taxon found in this study (Table 4), and together with surface feeding cirratulid and sabellid polychaetes, were responsible for the majority of microalgal-C-uptake after $48 \mathrm{~h}$ in sediments from the removal and control habitats (Table 4). When C-uptake rates were normalized to biomass, corophiid amphipods were responsible for the highest $\mathrm{C}$-uptake rates measured (Table 4). Interestingly, mean C-uptake rates (normalized to biomass) of spionids and oligochaetes fluctuated as a function of sampling site with spionid and oligochaete C-uptake rates being higher in both control experiments relative to the PHR and KBR studies (Table 4). Mean C-uptake rates by sedimentary bacteria within both control site experiments were approximately $16-45 \%$ of those found in sediments collected from the PHM and both removal habitats (Figs. 7d and 8d, Table 3), yet mean bacterial C-uptake was not significantly different between the Pearl Harbor studies $(P=0.286)$. Bacterial C-uptake was significantly higher in the KBR versus the KBC experiments ( $P=0.013$, Fig. 8 d). Mean bacterial $\mathrm{C}$-uptake decreased with sediment depth in cores in all Pearl Harbor (Fig. 7e) and Kaneohe Bay studies (Fig. 8e).

\section{Discussion}

Numerous studies have shown that invasive marsh grass and mangroves can modify essential habitat properties (e.g. porewater salinity, organic C-content, detrital food-supply), benthic biodiversity, and trophic structure through alterations in habitat complexity by the production of above and belowground biomass (Demopoulos, 2004; Neira et al., 2005; Levin et al., 2006; Demopoulos et al., 2007; Demopoulos and Smith, 2010). But to the best of our knowledge, this is the first study to address how an invasive vascular plant can modify sediment metabolism, as well as examine changes to benthic ecosystem processes as a function of the removal of above-sediment invasive mangrove biomass. In the invasive mangrove sediments sampled in this case study, macrofauna biomasses were reduced relative to microbial biomass, the macrofauna community was dominated by sub-surface feeding tubificid oligochaetes, and C-uptake of labile $\mathrm{C}$ was dominated by bacteria. Thus, in agreement with our hypothesis (1), biogeochemical cycling in the mangrove sediments favored bacterial pathways, yielding lower macrofauna uptake of labile organic matter than in the control experiments. Bacterial C-uptake and bacterial biomass were significantly enhanced in sediments from the KBR site compared to Kaneohe Bay control, but not in sediments recovered from the PHR site (relative to the PHC study). Thus, hypothesis (2) is partially supported. Nonetheless, SMB persisted in sediments from mangrove removal sites for at least 6-yrs, and additional ecosystem functioning parameters in both removal site experiments differed significantly from the controls by exhibiting higher SOC rates, higher macrofauna $\mathrm{C}$-uptake rates, and higher macrofauna abundances. There

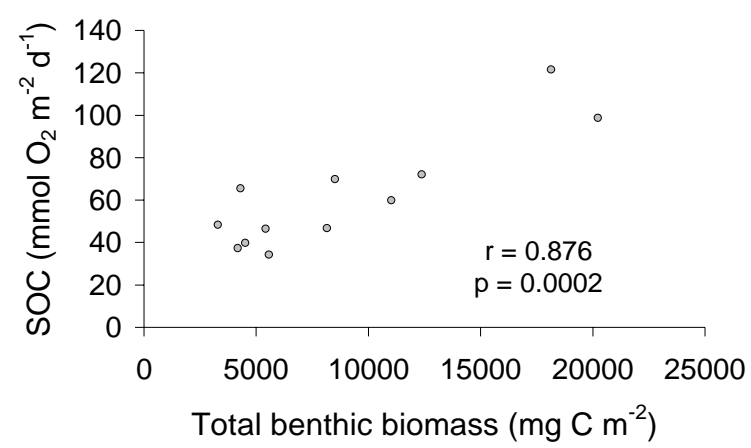

Fig. 5. Relationship between $\mathrm{SOC}\left(\mathrm{mmol} \mathrm{O}_{2} \mathrm{~m}^{-2} \mathrm{~d}^{-1}\right)$ and total benthic (macrofauna and bacteria) biomass $\left(\mathrm{mg} \mathrm{C} \mathrm{m}^{-2}\right)$.

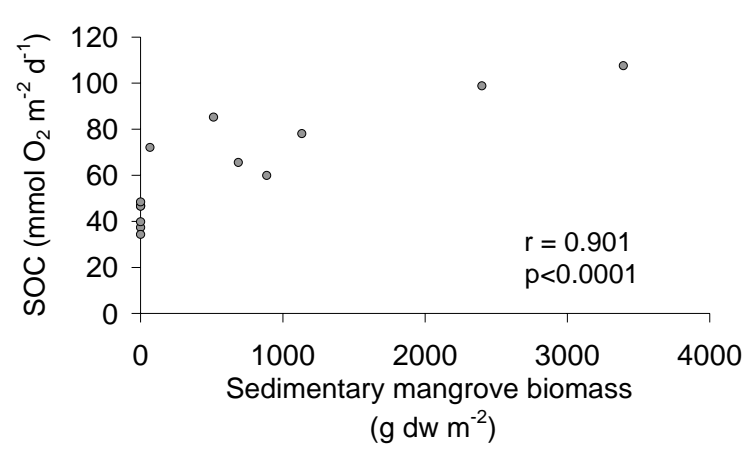

Fig. 6. Relationship between SOC $\left(\mathrm{mmol} \mathrm{O}_{2} \mathrm{~m}^{-2} \mathrm{~d}^{-1}\right)$ and sedimentary mangrove biomass $\left(\mathrm{g} \mathrm{dw} \mathrm{m}^{-2}\right)$.

are limitations associated with this case-study as a result of the short duration of each experiment (i.e. only $48 \mathrm{~h}$ ) and algal-C only being added to the sediment surface. These limitations therefore only allowed clarification of differences in near-surface processes in the different sediments studied. However, the experiments revealed dramatic differences between mangrove, mangrove removal and control sites in the depth distribution of labeled C-uptake by fauna and bacteria. Therefore, our results collectively show that major aspects of ecosystem function in sediments from an invasive mangrove forest can differ from those in un-invaded habitats, as well as highlight that ecosystem functioning in sediments from mangrove removal sites can differ substantially from those in control sites 2-6yrs after above-sediment mangrove removal.

SOC provides a good measure of depth-integrated community metabolism (Middelburg et al., 2005). In our study, we added a small quantity of labile organic matter (Chlorella spp. algae) to each experimental chamber, which represented between $0.2-2 \%$ of the C-stock in the first $5 \mathrm{~cm}$ of sediment. Nevertheless, daily production of DIC from the added phytodetritus accounted for between $10.59 \pm 1.49$ (range, $n=2$ ) to $10.91 \pm 0.26$ (SE, $n=3) \mathrm{mmol} \mathrm{C} \mathrm{m}^{-2} \mathrm{~d}^{-1}$ in the mangrove and removal site experiments and $7.67 \pm 0.71$ (SE, $n=3$ ) 
to $12.25 \pm 0.28$ ( $\mathrm{SE}, n=3$ ) $\mathrm{mmol} \mathrm{C} \mathrm{m}^{-2} \mathrm{~d}^{-1}$ in the controls, based on a molar mass weight for $\mathrm{C}$ of 12 . Assuming a respiratory quotient between DIC and $\mathrm{O}_{2}$ of 1 (Middelburg et al., 2005), this transfer of algal-C into daily respired DIC corresponded to approximately 10 to $17 \%$ of the SOC (or $4-12 \%$ of the mean total daily DIC efflux) in the mangrove and removal site experiments compared to 18 to $30 \%$ of the SOC (or $3-8 \%$ of the mean total daily DIC efflux) in the $\mathrm{PHC}$ and $\mathrm{KBC}$ site studies. These results highlight the very labile nature of the added algal-C-source and suggest that the measured SOC and total daily DIC efflux values may be higher than background values without algal addition. Nevertheless, SOC rates measured in the PHM experiments were quite similar to those found in previous mangrove studies (Nedwell et al., 1994; Middelburg et al., 1996; Alongi et al., 2000; Alongi, 2009), and overall rates were strongly correlated with total benthic (macrofauna and bacteria) biomass, which is consistent with other studies (e.g., Bolam et al., 2002). This strong correlation suggests that the significantly elevated bacterial biomass in sediment cores from the PHM and KBR sites, in addition to the large macrofauna biomasses found in sediments from both removal sites, played a major role in stimulating sediment $\mathrm{O}_{2}$ demand in the mangrove and removal site experiments. In addition, sediment $\mathrm{O}_{2}$ consumption was strongly correlated with SMB. We hypothesize that the presence of leaf litter and root-fiber material in sediments from the mangrove and removal habitats promoted sediment community metabolism, most likely because the release of DOC and DON from SMB provided microbial substrates (Boto et al., 1989; Alongi et al., 1989; Alongi and Sasekumar 1992; Robertson et al., 1992; Alongi, 2009). Because of the high heterogeneity of mangrove habitats (Kristensen, 2007), and the fact that sediments were recovered from only a relatively small area at each site (i.e. along a $15 \mathrm{~m}$ long transect), we are cautious to generalize the results of our case study to a wide geographic area. However, if the SOC results from this study are representative of other removal sites in Hawaii, the presence of SMB and the apparent enhancement of SOC in the removal site experiments (relative to the controls) after 6-yrs suggests that restoration of native sediment ecosystem function following mangrove clearing could require many years in Hawaii. Because root-fiber mats in native stands of the mangrove $R$. mangle in Florida and central America show similar decomposition rates (ranging from $\sim 17$ to $60 \%$ of biomass lost $\mathrm{yr}^{-1}$ [McKee et al., 2007; Poret et al., 2007; Alongi, 2009]) to those estimated here for Hawaii $\left(\sim 12-36 \%\right.$ of biomass lost $\left.\mathrm{yr}^{-1}\right)$, we hypothesize that sediment ecosystem function may be impacted for years following above-sediment mangrove removal even in native $R$. mangle stands.

With the exception of mangroves trees, bacteria dominate biomass and are the primary players in terms of energy-flow in native mangrove ecosystems (Alongi, 2002), deriving energy from autochthonous and allochthonous particulate and dissolved organic material (Bouillon et al., 2002), such as tannins, sugars and ligninocelluloses (Benner and Hodson, 1985; Boto et al., 1989; Alongi et al., 1989; Alongi, 2009). Our findings that the bacteria accounted for approximately 25 -fold greater benthic biomass and 15 -fold greater shortterm $\mathrm{C}$-uptake rates than the macrofauna in sediments from the invasive mangrove habitat are consistent with the bacterial dominance documented for sediments within native mangrove forests (e.g. Alongi, 2002, 2008; Kristensen, 2007; Kristensen et al., 2008). The addition of labile algal-C to the sediment surface in each experiment was, in all likelihood, one of the main factors driving the high algal-C-uptake rates by bacteria at $0-2 \mathrm{~cm}$ in each experiment. In experiments using cores collected from the PHM site and from both mangrove removal sites, upward diffusion of DOC from sub-surface root material may have also stimulated bacterial growth at the sediment surface (Boto et al., 1989; Kristensen and Alongi, 2006), which may have contributed to the elevated bacterial biomasses (and C-uptake rates) in surficial sediment layers in the mangrove and removal site experiments (especially the KBR study). The high bacterial biomass and activity in surface sediments of cores from the PHM site may also have been stimulated by the mangrove leaves at the sediment surface, which are known to be capable of hosting abundant bacterial populations (Mfilinge et al., 2003).

Sediments within low energy mangrove forests are often organically enriched compared to non-mangrove habitats as a result of the deposition of plant litter and the trapping of allochthonous material in emergent vegetation (Bosire et al., 2003; Kristensen, 2007). In our study, high organic loading was indicated in sediments from the PHM site by (1) the high sediment POC content found in the un-amended control ( $\sim 8 \%$ POC, Table 1) and (2) the positive correlation between SMB and POC (see methods section) combined with large amounts of SMB within sediments from the PHM site (Fig. 2a). Organic loading in sediments from the PHR was intermediate $(\sim 3 \%$ POC, Table 1, Fig. 2a), while sediment organic concentrations in cores from the PHC site were relatively low $(\sim 0.5 \%$ POC, no SMB, Table 1$)$. Macrofauna abundance and biomass in the PHM sediments were relatively low (compared to cores from the PHR site) and dominated by few potentially opportunistic taxa (oligochaetes and capitellids) suggesting sediment-community disturbance from high organic loading (Pearson and Rosenberg, 1979; Weston, 1990; Nilsson and Rosenberg, 1997, 2000; Hyland et al., 2005). The relatively low macrofauna density and biomass in the PHM experiments also could have resulted in part from large concentrations of tannins and tannin-rich mangrove biomass in the sediments negatively affecting the reproduction and growth of native Hawaiian biota poorly adapted to tannin stress (Alongi, 1987; Tietjen and Alongi, 1990; Demopoulos et al., 2007). The PHR sediments had elevated macrofauna biomass, and elevated abundances of macrofauna and capitellids, combined with intermediate levels of organic enrichment compared to PHC sediments; this 

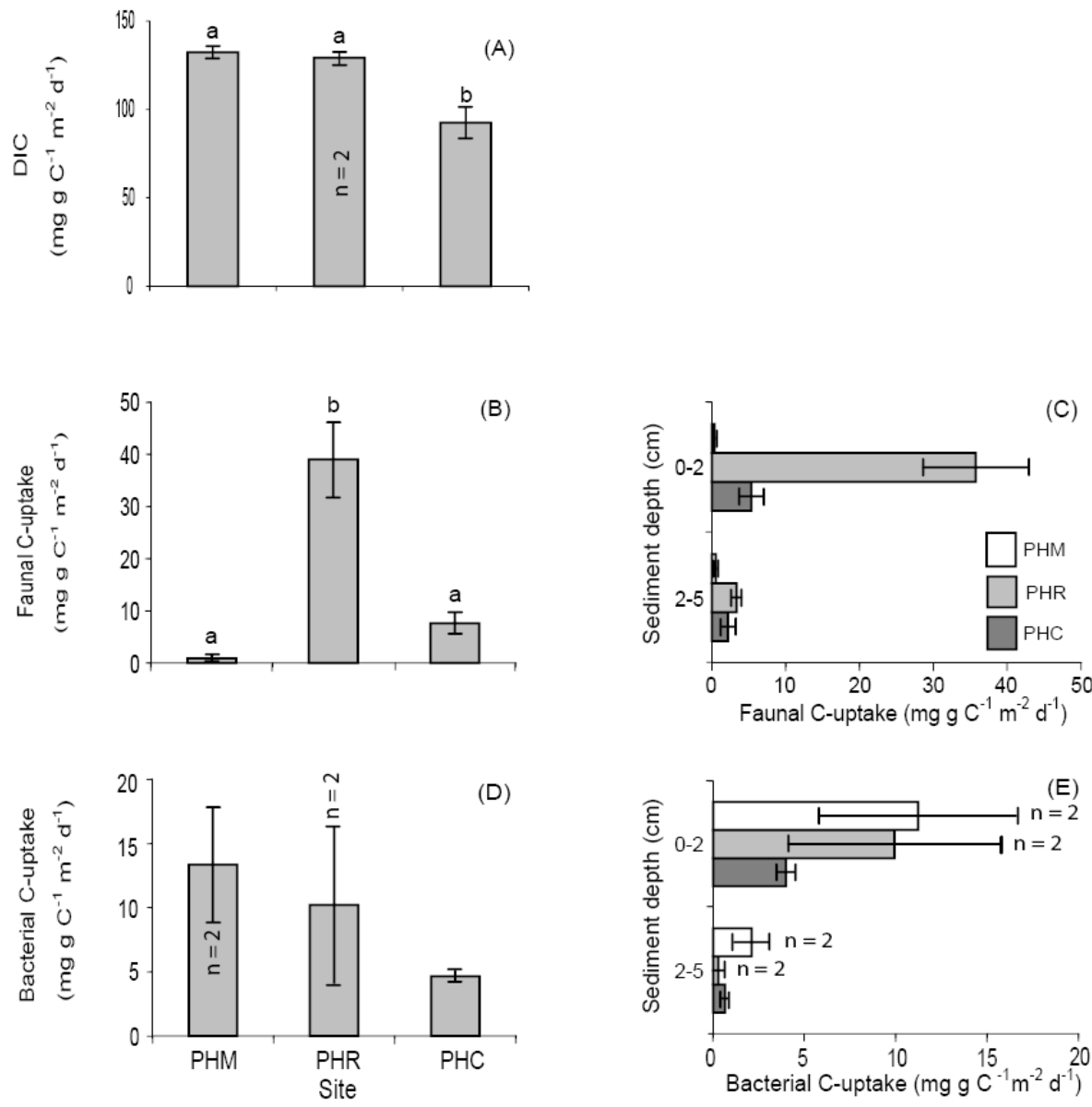

Fig. 7. Total production of DIC (A) from added algal-C in cores collected from all Pearl Harbor sites. Total and vertical distribution of macrofauna C-uptake (B and $\mathbf{C}$, respectively) and bacterial C-uptake ( $\mathbf{D}$ and $\mathbf{E}$, respectively) in cores from all Pearl Harbor sites are shown. Significant differences $(P<0.05)$ in parameters between sites are designated by different letters. Error bars denote \pm 1 SE $(n=3)$ unless $n=2$, where error bars denote \pm range of two samples because of insufficient sample for analysis from a 3rd replicate chamber.

pattern suggests the presence of intermediate stages of recolonization and recovery from organic loading in sediments from the PHR site, which are often associated with biomass maxima (e.g., Pearson and Rosenberg, 1978; Hyland et al., 2005). The KBR sediments also showed enhanced macrofauna abundance, capitellid abundance, SMB, and POC concentrations relative to control sediments in Kaneohe Bay, suggesting that this community was still at an intermediate stage of recovery 6-yrs after removal of above-sediment mangrove vegetation.

In the present study, macrofauna from the mangrove site were dominated by sub-surface deposit feeding tubificid oligochaetes (Ciutat et al., 2006; Giere, 2006), which agrees with previous mangrove and salt-marsh studies showing dominance by tubificids (Schrijvers et al., 1995; Levin et al., 2006). Their dominance in the community may be a function of their ability to cope with hypoxic and sulphidic conditions (Giere, 2006). However, the small, slender body size of tubificids may also allow them to easily inhabit the dense, root fiber network present in mangrove sediments (Levin et al., 1998; Demopoulos, 2004).

Faunal-mediated uptake of added $\mathrm{C}$ was significantly lower in sediment cores collected from the PHM site than in the PHR study (Fig. 7b, Table 3), and appeared to be partly attributable to the low (relative to the PHR experiments) macrofauna biomasses found in these cores (Bolam et al., 2002). However, faunal communities in cores from the PHM site were dominated by sub-surface feeding taxa (e.g. oligochaetes and capitellid polychaetes), and more fauna were found deeper in the sediment column $\left(14365 \pm 6833 \mathrm{~m}^{-2}, \mathrm{SE}, n=3\right.$, see Fig. $\left.3 \mathrm{~b}\right)$ compared to at the surface $\left(7233 \pm 5908 \mathrm{~m}^{-2}, \mathrm{SE}, n=3\right.$, see Fig. 3b), which may have collectively limited the ability of the faunal community to process $\mathrm{C}$ deposited at the sediment surface. In addition, mangrove leaf litter on the surface of PHM cores may have acted as a barrier to algal mixing during the $48 \mathrm{~h}$ experiments, limiting the subduction of added $\mathrm{C}$ to the sub-surface feeding fauna (Dobbs and Whitlach, 

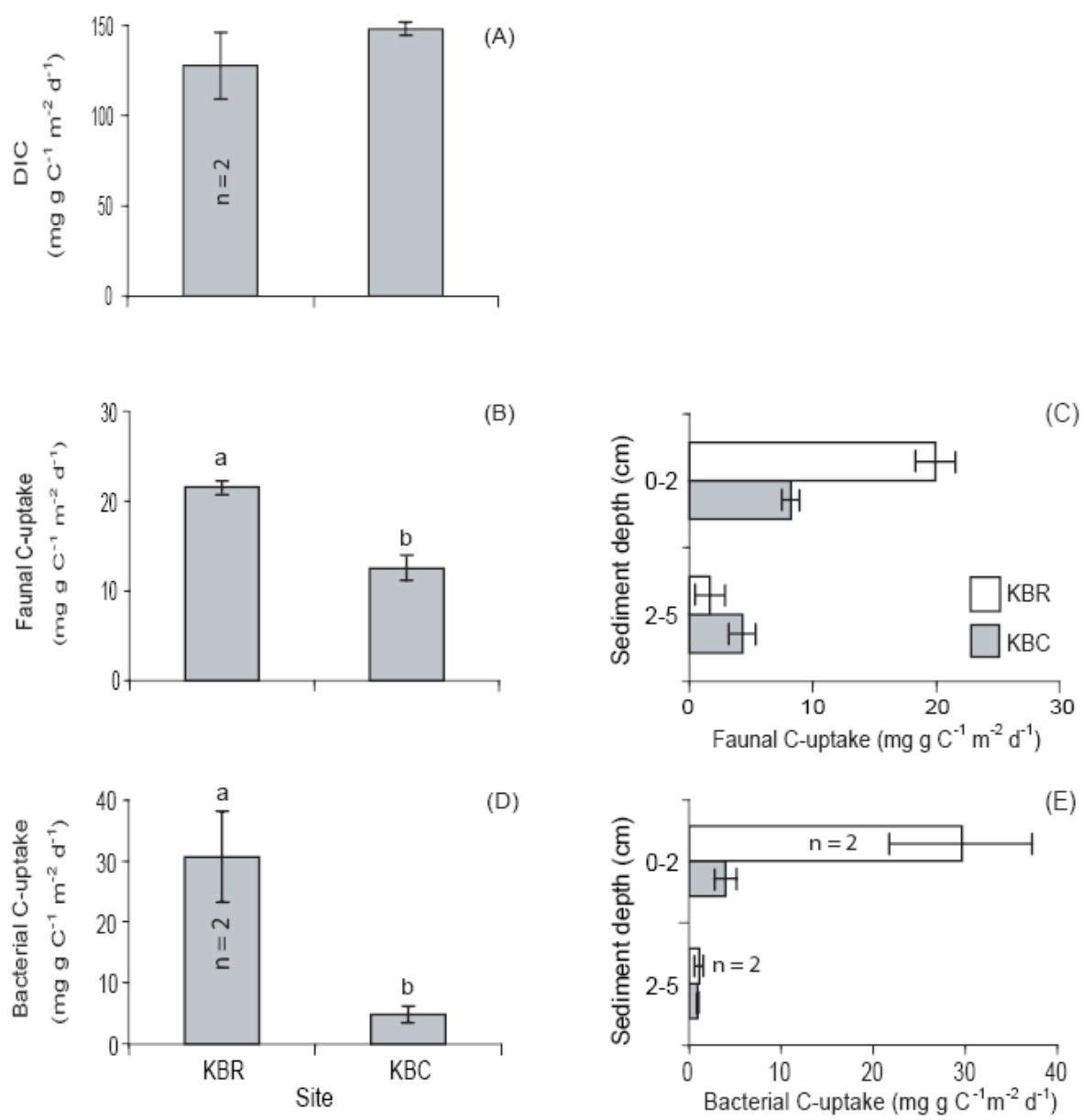

Fig. 8. Total production of DIC (A) from added algal-C in cores collected from all Kaneohe Bay sites. Total and vertical distribution of macrofauna C-uptake (B and $\mathbf{C}$, respectively) and bacterial C-uptake (D and E, respectively) in cores from all Kaneohe Bay sites are shown. Significant differences $(P<0.05)$ in parameters between sites are designated by different letters. Error bars denote \pm 1 SE $(n=3)$ unless $n=2$, where error bars denote \pm range of two samples because of insufficient sample for analysis from a 3rd replicate chamber.

1982; Levin et al., 1997). In the PHR and PHC experiments, no leaf litter occurred atop sediments and a much higher proportion of the macrofauna belonged to surface and suspension feeding guilds (e.g. spionids, cirratulids, and sabellids, see Table 2). These factors likely explain the significantly higher $\mathrm{C}$-uptake rates by macrofauna in the mangrove removal and control sediments compared to the mangrove site experiments. Likewise, suspension and surface feeding macrofauna (e.g. corophiids, sabellids, see Table 2) were highly abundant and made up a major part of the biomass (e.g. corophiids, spionids, see Table 2) in sediments recovered from the Kaneohe Bay sites, and contributed heavily to the large (relative to the PHM study) faunal C-uptake rates measured here (Table 4). In terms of C-uptake rates normalized to biomass, the apparent increase in response to labile $\mathrm{C}$ by similarly related taxa (e.g. oligochaetes, spionids, see Table 4) in the control studies, relative to the removal sites, may have resulted from lower faunal densities in control sediments (see Table 2) stimulating deposit feeding as seen in previous studies (Miller and Jumars, 1986; Wheatcroft et al., 1998). Altogether, these results suggest that both habitat and macrofauna-community structure may be important in regulating the fate of sedimented phytodetritus in invasive mangrove forests and other shallow marine ecosystems along the Hawaiian coastal zone (cf. Josefson et al., 2002; Kamp and Witte, 2005).

While surface and suspension feeding lifestyles appeared to be an important determinant in structuring the high macrofauna $\mathrm{C}$-uptake rates in sediment cores recovered from the removal and control sites (relative to the PHM study), significantly higher $\mathrm{C}$-uptake rates were found in both removal site experiments relative to the controls, suggesting that additional factors were at play. Macrofauna abundance and biomass were elevated in sediment cores recovered from the removal sites compared to controls, and a much larger proportion of macrofauna abundance and biomass was found in surficial sediment layers in cores from the removal habitats (see Figs. 3a to d, 4a to d). Therefore, because of 
the higher macrofauna standing stock near the sediment surface, macrofauna likely had the ability to cycle through and process newly deposited organic matter more rapidly in the removal site experiments, than communities residing in sediment cores recovered from the control sites, and is possibly the main factor behind the significantly different faunal $\mathrm{C}$ uptake rates measured between the removal site experiments and controls.

Overall, the faunal and bacterial C-uptake results suggest that surface-living bacteria rather than deeper-dwelling macrofauna can contribute significantly more to the shortterm cycling of labile organic matter, such as phytodetritus (Bouillon et al., 2002, 2004, 2008), in sediments from invasive mangrove forests in Hawaii as well as in specific removal areas (i.e. the KBR site). The opposite appears to be true for sediments from the Pearl Harbor removal habitat and un-invaded mudflats on O'ahu, where macrofauna appeared to be more dominant players in the early diagenesis of microalgal-C. However, our data from the PHR and KBR experiments suggest that mangrove invasion and removal in Hawaii can have a major, lasting effect on benthic biotic structure and C-cycling dynamics, and we hypothesize that in Hawaii, and other areas where native mangrove species ranges are increasing (e.g. the New Zealand coast), ecosystem recovery following mangrove removal may involve intermediate stages in which macrofauna, as well as bacterial standing stocks, and contributions to short-term microalgalC-cycling are substantially enhanced compared to adjacent un-vegetated mudflats. In order to apply these results to other areas with mangroves in Hawaii, more exhaustive short- and long-term feeding studies using different types of labeled phytoplankton and mangrove detritus (Oakes et al., 2010) must now be undertaken in a diverse range of mangrove habitats (i.e. high intertidal to subtidal, areas of extreme vs. little burrowing activity) over a variety of temporal scales to better quantify the variability in C-cycling dynamics in sediments in invasive mangrove forests and deforested habitats.

\section{Conclusions}

Invasive mangroves in Hawaii can significantly elevate sediment $\mathrm{O}_{2}$ demand, and elevated SOC rates can persist for at least 6-yrs after above-sediment mangrove removal. Bacterial C-processing can become enhanced, relative to macrofauna, in near-surface sediments from intact mangrove habitats, suggesting that bacteria dominate short-term C-cycling in sediments within invasive mangrove forests in Hawaii. Bacterial dominance of short-term C-cycling in sediments from Hawaiian mangrove forests is similar to early diagenetic processes in native mangrove forests (Alongi, 2002, 2008; Kristensen, 2007; Kristensen et al., 2008). In sediments from the Pearl Harbor mangrove removal area, macrofauna dominated short-term microalgal-C remineralization, similarly to mangrove-free mudflats. However, key benthic ecosystem properties in sediments from mangrove removal sites such as macrofauna abundance, bacterial biomass, short-term microalgal-C-uptake by macrofauna and bacteria, and SOC can remain significantly different compared to controls for up to 6-yrs following mangrove-tree removal. This case study demonstrates that invasive mangroves can have large and persistent impacts on ecosystem function in the Hawaiian coastal zone, and highlights the need for further work to determine the generality of these findings.

Acknowledgements. We thank Roy Tom and Mike Cole (UH) for their help in building our benthic chambers and stirring system, and Fabio DeLeo, Pavica Srsen, Elizabeth Galley, and Iris Altimira (UH) for all their help in carrying out experiments. We express deep gratitude to Andy Rossiter and Jerry Crow and others at Waikiki Aquarium for their time and patience while we conducted our experiments in 2008. Thanks to Randy Miyashiro, the US Navy Pacific Fleet and the Pearl Harbor Wildlife Refuge for help with sampling permits and to Dave Karl for use of his titration equipment. We are indebted to Robert Toonen and Ruth Gates at the Hawaii Institute for Marine Biology for use of their laboratory, and David Harris (UC Davis) and Pieter van Rijswijk (Netherlands Institute of Ecology) for help in sample analyses. We would also like to thank Steve Bouillon, Rod Connolly, Erik Kristensen, Mark Huxham, Kylie Pitt and two anonymous reviewers whose comments assisted us in improving the manuscript. This research was funded by a University of Hawaii Sea Grant Project (NOAA Grant \#: NA05OAR4171048) to AKS and CRS. Use of trade, product, or firm names does not imply endorsement by the US Government. This is publication no. 7918 from the School of Ocean and Earth Science and Technology, UH.

Edited by: S. Bouillon

\section{References}

Alongi, D. M.: The influence of mangrove derived tannins on intertidal meiobenthos in tropical estuaries, Oecologia, 71, 537-540, 1987.

Alongi, D. M., Boto, K. G., and Tirendi, F.: Effect of exported mangrove litter on bacterial productivity and dissolved organic carbon fluxes in adjacent tropical nearshore sediments, Mar. Ecol. Prog. Ser., 56, 133-144, 1989.

Alongi, D. M. and Sasekumar, A.: Benthic communities, in: Tropical mangrove ecosystems, American Geophysical Union, Washington DC, USA, 137-171, 1992.

Alongi, D. M., Tirendi, F., and Clough, B. F.: Below-ground decomposition of organic matter in forests of the mangroves Rhizophora stylosa and Avicennia marina along the arid coast of Western Australia, Aquat. Bot., 68, 97-122, 2000.

Alongi, D. M.: Present state and future of the world's mangrove forests, Environ. Conserv., 29, 331-349, 2002.

Alongi, D. M.: Energetics of Mangrove Forests, Springer, New York, USA, 2009.

Benner, R., and Hodson, R. E.: Microbial degradation of the leachable and lignocellulosic components of leaves and wood from Rhizophora mangle in a tropical mangrove swamp, Mar. Ecol. Prog. Ser., 23, 221-230, 1985. 
Bolam, S. G., Fernandes, T. F., and Huxham, M.: Diversity, biomass and ecosystem processes in the marine benthos, Ecol. Monogr., 72, 599-615, 2002.

Boschker, H. T. S. and Middelburg, J. J.: Stable isotopes and biomarkers in microbial ecology, FEMS. Microbial. Ecol., 40, 85-95, 2002.

Bosire, J. O., Dahdouh-Guebas, F., Kairo, J. G., and Koedam, N.: Colonization of non-planted mangrove species into restored mangrove stands in Gazi Bay, Kenya, Aquat. Bot., 76, 267-279, 2003.

Boto, K. G., Alongi, D. M., and Nott, A. L. J.: Dissolved organic carbon-bacteria interactions at sediment-water interface in a tropical mangrove system, Mar. Ecol. Prog. Ser., 51, 243-251, 1989.

Bouillon, S., Koedam, N., Raman, A. V., and Dehairs, F.: Primary producers sustaining macro-invertebrate communities in intertidal mangrove forests, Oecologia, 130, 441-448, 2002.

Bouillon, S., Moens, T., Overmeer, I., Koedam, N., and Dehairs, F.: Resource utilization patterns of epifauna from mangrove forests with contrasting inputs of local versus imported organic matter, Mar. Ecol. Prog. Ser., 278, 77-88, 2004.

Bouillon, S., Connolly, R. M., and Lee, S. Y.: Organic matter exchange and cycling in mangrove ecosystems: recent insight from stable isotope studies, J. Sea. Res., 59, 44-58, 2008.

Brinch-Iversen, J., and King, G. M.: Effects of substrate concentration, growth state, and oxygen availability on relationships among bacterial carbon, nitrogen and phospholipids phosphorous content, FEMS. Microbiol. Ecol., 74, 345-356, 1990.

Bromberg-Gedan, K., Silliman, B. R., and Bertness, M. D.: Centuries of human-driven change in salt marsh ecosystems, Annu. Rev. Mar. Sci., 1, 117-141, 2009.

Chimner, R. A., Fry, B., Kaneshiro, M. Y., and Cormier, N.: Current extent and historical expansion of introduced mangroves on O'ahu, Hawaii, Pac. Sci., 60, 377-383, 2006.

Ciutat, A., Weber, O., Gérino, M., and Boudou, A.: Stratigraphic effects of tubificids in freshwater sediments: a kinetic study based on X-ray images and grain size analysis, Acta. Oecol., 30, 228237, 2006.

Demopoulos, A. W. J.: Aliens in paradise: a comparative assessment of introduced and native mangrove benthic community composition, food-web structure, and litter-fall production, Ph.D. thesis, University of Hawaii, USA, 252pp., 2004.

Demopoulos, A. W. J., Fry, B., and Smith, C. R.: Food-web structure in exotic and native mangroves: a Hawaii-Puerto Rico comparison, Oecologia, 153, 675-686, 2007.

Demopoulos, A. W. J. and Smith, C. R.: Invasive mangroves alter macrofaunal community structure and facilitate opportunistic exotics, Mar. Ecol. Prog. Ser., 404, 51-67, 2010.

Dobbs, F. C., and Whitlatch, R. B.: Aspects of deposit-feeding by the polychaete Clymenella torquata, Ophelia, 21, 159-166, 1982.

Mangroves: Nature's defence against Tsunamis - A report on the impact of mangrove loss and shrimp farm development on coastal defences, Env. Just. Foun., London, UK, 30pp., 2006.

Evrard, V., Kiswara, W., Bouma, T. J., and Middelburg, J. J.: Nutrient dynamics of seagrass ecosystems: ${ }^{15} \mathrm{~N}$ evidence for the importance of particulate organic matter and root systems, Mar. Ecol. Prog. Ser., 295, 49-55, 2005.

Fauchald, K. and Jumars., P. A.: The diet of worms: A study of polychaete feeding guilds, Oceanogr. Mar. Biol. Ann. Rev., 17,
193-284, 1979.

Giere, O.: Ecology and biology of marine oligochaeta - an inventory rather than another review, Hydrobiologia, 564, 103-116, 2006.

Grasholz, E.: Ecological and evolutionary consequences of coastal invasions, Trends. Ecol. Evol., 17, 22-27, 2002.

Grasshoff, K., Kremling, K., and Ehrhardt, M.: Methods of seawater analysis. Wiley, Hoboken, New Jersey, USA, 1999.

Harley, C. D. G., Randall Hughes, A., Hultgren, K. M., Miner, B. G., Sorte, C. J. B., Thornber, C. S., Rodriguez, L. F., Tomanek, L., and Williams, S. L.: The impacts of climate change in coastal marine systems, Ecol. Lett., 9, 228-441, 2006.

Hyland, J., Balthis, L., Karakassis, I., Magni, P., Petrov, A., Shine, J., Vestergaard, O., and Warwick, R.: Organic carbon content of sediments as an indicator of stress in the marine benthos, Mar. Ecol. Prog. Ser., 295, 91-103, 2005.

Josefson, A. B., Forbes, T. L., and Rosenberg, R.: Fate of phytodetritus in marine sediments: functional importance of macrofauna community, Mar. Ecol. Prog. Ser., 230, 71-85, 2002.

Kamp, A. and Witte, U.: Processing of ${ }^{13} \mathrm{C}$-labeled phytoplankton in a fine-grained sandy-shelf sediment (North Sea): relative importance of different macrofauna species, Mar. Ecol. Prog. Ser., 297, 61-70, 2005.

Kristensen, E. and Alongi, D. M.: Control by fiddler crabs (Uca vocans) and plant roots (Avicennia marina) on carbon, iron, and sulfur biogeochemistry in mangrove sediment, Limnol. Oceanogr., 51, 1557-1571, 2006.

Kristensen, E.: Carbon balance in mangrove sediments: the driving processes and their controls, in: Greenhouse Gas and Carbon Balances in Mangrove Coastal Ecosystems, Gendai Tosho, Kanagawa, Japan, 61-78, 2007.

Kristensen, E., Bouillon, S., Dittmar, T., and Marchand, C.: Organic carbon dynamics in mangrove ecosystems: A review, Aquat. Bot., 89, 201-219, 2008.

Levin, L. A., Blair, N., DeMaster, D., Plaia, G., Fornes, W., Martin, C., and Thomas, C.: Rapid subduction of organic matter by maldanid polychaetes on the North Carolina Slope, J. Mar. Res., 55, 595-611, 1997.

Levin, L. A., Talley, T. S., and Hewitt, J.: Macrobenthos of Spartina foliosa (Pacific cordgrass) salt marshes in southern California: community structure and comparison to a Pacific mudflat and a Spartina alterniflora (Atlantic smooth cordgrass) marsh, Estuaries, 21, 129-144, 1998.

Levin, L. A., Neira, C., and Grosholz, E. D.: Invasive cordgrass modifies wetland ecosystem function, Ecology, 87, 419-432, 2006.

Mahadevan, A. and Muthukumar, G.: Aquatic microbiology with reference to tannin degradation, Hydrobiologia, 72, 73-79, 1980.

McKee, K. L., Cahoon, D. R., and Feller, I. C.: Caribbean mangroves adjust to rising sea level through biotic controls on change in soil elevation, Global. Ecol. Biogeog., doi:10.1111/j.14668238.2007.00317.x., 2007.

Mfilinge, P. L., Meziane, T., Bachok, Z., and Tsuchiya, M.: Fatty acids in decomposing mangrove leaves: microbial activity, decay and nutritional quality, Mar. Ecol. Prog. Ser., 265, 97-105, 2003.

Middelburg, J. J., Nieuwenhuize, J., Slim, F. J., and Ohowa, B.: Sediment biogeochemistry in an East African mangrove forest (Gazi Bay, Kenya), Biogeochemistry, 34, 133-155, 1996.

Middelburg, J. J., Barranguet, C., Boschker, H. T. S., Herman, P. 
M. J., Moens, T., and Heip, C. H. R.: The fate of inter-tidal microphytobenthos carbon: An in situ ${ }^{13}$ C-labeling study, Limnol. Oceanogr., 45, 1224-1234, 2000.

Middelburg, J. J., Duarte, C. M., and Gattuso, J. P.: Respiration in coastal benthic communities, in: Respiration in Aquatic Ecosystems, Oxford University Press, Oxford, UK, 206-224, 2005.

Miller, D. C. and Jumars, P. A.: Pellet accumulation, sediment supply and crowding as determinants of surface deposit-feeding rate in Pseudopolydora kempi japonica Imajima and Hartman (Polychaeta: Spionidae), J. Exp. Mar. Biol. Ecol., 99, 1-17, 1986.

Moodley, L., Boschker, H. T. S., Middelburg, J. J., Pel, R., Herman, P. M. J., De Deckere, E., and Heip, C. H. R.: Ecological significance of benthic foraminifera: ${ }^{13} \mathrm{C}$-labeling experiments, Mar. Ecol. Prog. Ser., 202, 289-295, 2000.

Nagelkerken, I., Blaber, S. J. M., Bouillon, S., Green, P., Haywood, M., Kirton, L. G., Meynecke, J. O., Pawlik, J., Penrose, H. M., Sasekumar, A., and Somerfield, P. J.: The habitat function of mangroves for terrestrial and marine fauna: a review, Aquat. Bot. 89., 155-185, 2008.

Nedwell, D. B., Blackburn, T. H., and Wiebe, W. J.: Dynamic nature of the turnover of organic carbon, nitrogen and sulphur in the sediments of a Jamaican mangrove forest, Mar. Ecol. Prog. Ser., 110, 223-231, 1994.

Neilson, M. J., Giddins, R. L., and Richard, G. N.: Effects of tannins on the palatability of mangrove leaves to the tropical sesarminid crab Neosarmatium smithi, Mar. Ecol. Prog. Ser., 34, 185-186, 1986.

Neira, C., Levin, L. A., and Grosholz, E. D.: Benthic macrofauna communities of three sites in San Francisco Bay invaded by hybrid Spartina, with comparison to un-invaded habitats, Mar. Ecol. Prog. Ser., 292, 111-126, 2005.

Nilsson, H. C. and Rosenberg, R.: Benthic habitat quality assessment of an oxygen stressed fjord by surface and sediment profile images, J. Mar. Sys., 11, 249-264, 1997.

Nilsson, H. C. and Rosenberg, R.: Succession in marine benthic habitats and fauna in response to oxygen deficiency: analysed by sediment profile-imaging and by grab samples, Mar. Ecol. Prog. Ser., 197, 139-149, 2000.

Oakes, J. M., Connolly, R. M., and Revill, A. R.: Isotope enrichment in mangrove forests separates microphytobenthos and detritus as carbon sources for animals, Limnol. Oceanogr., 55, 393402, 2010.

Pearson, T. H. and Rosenberg, R.: Macrobenthic succession in relation to organic enrichment and pollution of the marine environment, Oceanog. Mar. Biol. Annu. Rev., 16, 229-311, 1978.

Poret, N., Twilley, R. B., Rivera-Monroy, V. H., and CoronadoMolina, C.: Below-ground decomposition of mangrove roots in Florida coastal everglades, Estuar. Coasts., 30, 491-496, 2007.

Rajendran, N., Suwa, Y., Urushigawa, Y., and Simidu, U.: Distribution of phospholipid ester-linked fatty acid biomarkers for bacteria in the sediments of Ise Bay, Japan, Mar. Chem., 42, 39-56, 1993.
Robertson, A. I., Alongi, D. M., and Boto, K. G.: Food chains and carbon fluxes, in: Tropical mangrove ecosystems, American Geophysical Union, Washington DC, USA, 293-326, 1992.

Schrijvers, J., Van Gansbeke, D., and Vincx, M.: Macrobenthic infauna of mangroves and surrounding beaches of Gazi Bay, Kenya, Hydrobiologia, 306, 53-66, 1995.

Sessegolo, G.C. and Lana, P.C.: Decomposition of Rhizophora mangle, Avicennia schaueriana and Laguncularia racemosa leaves in a mangrove of Paranagua Bay (southeastern Brazil), Bot. Mar., 34, 285-289, 1991.

Sjöing, S., Mohammed, S. H., Lyimo, T. J., and Kyaruzi, J. J.: Benthic bacterial diversity and nutrient processes in mangroves: impacts of deforestation, Estuar. Coast. Shelf. Sci., 63, 397-406, 2005.

Sweetman, A. K., Sommer, S., Pfannkuche, O., and Witte, U.: Retarded response by macrofauna-size foraminifera to phytodetritus in a deep Norwegian fjord, J. Foram. Res., 39, 15-22, 2009.

Talley, T. S. and Levin, L. A.: Modification of sediments and macrofauna by an invasive marsh plant, Biol. Invas., 3, 51-68, 1999.

Tietjen, J. H. and Alongi, D. M.: Population growth and effects of nematodes on nutrient regeneration and bacteria associated with mangrove detritus from northeastern Queensland (Australia), Mar. Ecol. Prog. Ser., 68, 169-179, 1990.

Valiela, I. and Cole, M.L.: Comparative evidence that salt marshes and mangroves may protect seagrass meadows from land-derived nitrogen loads, Ecosystems, 5, 92-102, 2002.

Van Oevelen, D., Moodley, L., Soetaert, K., and Middelburg, J. J.: The trophic significance of bacterial carbon in a marine intertidal sediment: Results of an in-situ stable isotope labeling study, Limnol. Oceanogr., 51, 2349-2359, 2006.

Victor, S., Golbuu, Y., Wolanksi, E., and Richmond, R. H.: Fine sediment trapping in two mangrove-fringed estuaries exposed to contrasting land-use intensity, Palau, Micronesia, Wet. Ecol. Manage., 12, 277-283, 2004.

Wardle, D. A., Bardgett, R. D., Klironomos, J. N., Setälä, H., van der Putten, W. H., and Wall, D. H.: Ecological linkages between above-ground and below-ground biota, Science, 304, 1629-1633, 2004.

Wheatcroft, R. A., Starczak, V. R., and Butman, C. A.: The impact of population abundance on the deposit-feeding rate of a cosmopolitan polychaete worm, Limnol. Oceanogr., 43, 19481953, 1998.

Weston, D. P.: Quantitative examination of macrobenthic community changes along an organic enrichment gradient, Mar. Ecol. Prog. Ser., 61, 233-244, 1990.

Zar, J. H.: Biostatistical Analysis, Prentice Hall, New Jersey, USA, 1999.

Zavaleta, E. S., Hobbs, R. J., and Mooney, H. A.: Viewing invasive species removal in a whole-ecosystem context, Trends. Ecol. Evol., 16, 454-459, 2001. 